\title{
Financial Regulation, Financial Globalization and the Synchronization of Economic Activity*
}

\author{
Sebnem Kalemli-Ozcan \\ Koc University, Harvard University, CEPR and NBER \\ Elias Papaioannou \\ Dartmouth College, Harvard University, CEPR and NBER \\ José-Luis Peydró \\ Universitat Pompeu Fabra and Barcelona GSE
}

February 2012

\begin{abstract}
We analyze the impact of financial globalization on business cycle synchronization utilizing a proprietary database on banks' international exposure for industrialized countries during 19782006. Theory makes ambiguous predictions and identification has been elusive due to lack of bilateral time-varying financial linkages data. In contrast to conventional wisdom and previous empirical studies, we identify a strong negative effect of banking integration on output synchronization, conditional on global shocks and country-pair heterogeneity. Similarly, we show divergent economic activity as a result of higher integration using an exogenous de-jure measure of integration based on financial regulations that harmonized EU markets.
\end{abstract}

JEL Classification: E32, F15, F36, G21, G28

Keywords: Banking Integration, Co-movement, Contagion, Fluctuations, Finance

\footnotetext{
*This paper was previously circulated under the title, "Financial Integration and Business Cycle Synchronization." Essential parts of the paper were prepared while Sebnem Kalemli-Ozcan was visiting the European Central Bank as 2008 Duisenberg Fellow. She thanks the economists at the Bank for providing a stimulating research environment. We thank two anonymous referees, the associate editor, an advisor and Cam Harvey (the editor), John Campbell, Harris Dellas, Domenico Giannone, Jean Imbs, Simone Manganelli, Gian Maria Milesi-Ferretti, Bent Sørensen, Marco Pagano, Fabrizio Perri, Andrei Shleifer, Aaron Tornell, Francis Warnock, Axel Weber and seminar participants at UCLA, Brown, Dartmouth College, Harvard Business School, University of Maryland, the ECB, the Oesterreichische Nationalbank, ALBA, the 5th ECB Central Banking Conference, the BIS-CGFS Workshop on Global Financial Stability, CRETE, the CEPR-EUI workshop on Globalization, the NBER Summer Institute, the Federal Reserve Bank of Dallas, and the 2010 AEA Meetings for helpful comments and suggestions. Dimitrios Rakitzis provided excellent research assistance.
} 


\section{Introduction}

What is the role of global financial intermediaries in the international propagation of countryspecific shocks? This question is at the center of the current academic and policy debate involving global financial stability, new financial architecture, and monetary policy coordination. The $2007-$ 2008 financial crisis lead to heated debates on whether it was the outcome of a common shock to industrial countries' asset markets or whether financial globalization, banking integration in particular, has been the catalyst for amplifying and transmitting a moderate shock from a corner of the U.S. capital markets to the rest of the world.

Although we still lack direct evidence on these arguments, both find support in the observation that the synchronization of economic activity and financial globalization go in tandem. Yet this co-evolution does not necessarily imply a causal relationship. A fundamental problem with this view is the lack of systematic evidence for the benchmark: the co-movement of output and financial integration during tranquil periods of financial stability - i.e., how financial globalization affects output co-movement during normal times. If two financially integrated countries show a high degree of output and equity return synchronization during tranquil times, then a high correlation after one country experiences a financial shock does not necessarily constitute contagion. Contagion would emerge only if the synchronization of economic activity between financially integrated countries is higher after the shock, relative to the benchmark; conditional of course on common shocks and other factors that may simultaneously affect world market integration and business cycle synchro-

nization. A key question is then whether output co-movement has increased as a result of financial globalization during the last decades. In this paper we show that - in contrast to conventional wisdom and previous empirical studies - this is not the case.

Theoretically, the correlation between financial integration and business cycle synchronization is ambiguous. Both finance/banking and macroeconomic theoretical models make opposing predictions on the association between financial integration and the synchronization of economic activity, depending on whether financial shocks to the banking sector or collateral/productivity shocks to non-financial firms dominate. The commonality in both set of models is as follows: In a financially integrated world, if firms in certain countries are hit by negative (positive) shocks to their collateral or to their productivity, both domestic and foreign banks decrease (increase) lending in these countries and increase (decrease) lending in the non-affected countries, thereby causing a further divergence of output growth. In contrast, if the negative (positive) shock is to the banking sector, globally operating banks pull out funds from all countries, transmitting the domestic banking shock 
internationally, making business cycles of the two countries more alike. ${ }^{1}$

The identification of the one-way effect of financial integration on business cycle synchronization entails various empirical challenges. First, a positive association between cross-border financial linkages and output co-movement does not necessarily imply causation since such a relationship might be spuriously driven by commonalities between countries. Proximate countries with stronger economic, social, cultural, and political ties tend to have both more synchronized output fluctuations and stronger cross-border financial linkages. In fact, previous empirical studies show that most of the robust correlates of both output co-movement and financial integration are indeed factors related to proximity. ${ }^{2}$

Second, the response of integrated economies to common shocks will be similar. There has been a common trend in both financial globalization and synchronization of economic activity over the past decades. Figures 1 and 2 illustrate these patterns in our data. Yet the co-evolution of financial integration and output synchronization does not necessarily imply a causal relationship, as the common trend can be driven by other features of globalization, such as trade integration, outsourcing, increased coordination of monetary policy, and financial and/or real shocks that are common to all country-pairs. ${ }^{3}$

Third, a significant negative association between banking linkages and business cycle synchronization may reflect reverse causation from output dynamics to financial integration. International diversification benefits become larger when stock returns are less correlated across countries, and thus financial flows may increase among dissimilar economies. These return and growth differentials may also affect risk sharing/taking, which in turn affect financial integration. ${ }^{4}$

Fourth, measurement error in the bilateral data on international capital holdings might attenuate the estimates (or even lead to systematic biases). International capital holdings/flows data are far from perfect as they tend to miss indirect links via small financial centers, are usually based on

\footnotetext{
${ }^{1}$ See Holmstrom and Tirole (1997), Morgan, Rime, and Strahan (2004), Allen and Gale (2000), Perri and Quadrini (2001), Mendoza and Quadrini (2010), and Enders, Kollman and Muller (2010), among others. In Section 2 we discuss in detail the theoretical mechanisms and discuss previous empirical studies.

${ }^{2}$ Baxter and Kouparitsas (2005) show that geographic and cultural proximity variables are the most robust correlates of output synchronization. Portes and Rey (2005), Guiso, Sapienza, and Zingales (2009), Ekinci, Kalemli-Ozcan and Sørensen (2008), Giannetti and Yafeh (2008), Mian (2006), and Papaioannou (2009), among others, show that distance and cultural ties are strong correlates of international financial activities and banking in particular.

${ }^{3}$ See Rose (2009) and Inklaar, Jong-A-Pin, and de Haan (2008) on the business cycle synchronization effects of monetary policy and fiscal policy coordination, respectively.

${ }^{4}$ For the effect of financial integration on international risk sharing and volatility see Bekaert, Harvey, and Lundbad (2005, 2006, 2011), Bekaert, Harvey, Lundblad, Siegel (2007), Kose, Prasad, Rogoff, and Wei (2009), Kalemli-Ozcan, Sørensen, and Yosha (2001, 2003), Kalemli-Ozcan, Sørensen and Volosovych (2010), and Kalemli-Ozcan, Manganelli, Papaioannou, and Peydró (2009), among others.
} 
surveys, and are mostly available for the recent years.

Currently, the empirical and theoretical literatures are disconnected since only a proper identification that accounts for all of the above empirical challenges can credibly lend itself into a causal interpretation. This is the task we undertake in this paper. In contrast to previous empirical studies that mainly explored cross-sectional (cross-country) variation, our methodology for estimating the impact of financial integration on business cycle synchronization focuses on changes over time within more than 150 pairs of advanced economies over the period 1978-2006. Our panel estimates assess how the evolution of business cycle synchronization is affected when (de-facto and de-jure) bilateral financial integration changes within each country pair, conditional on common shocks, unobserved country-pair heterogeneity and hard-to-account-for dynamics. To the extent that this within country-pair comparison fully absorbs country-pair specific differences in synchronization and integration, the estimated difference can be plausibly attributed to changes in the degree of financial integration over time. To the best of our knowledge, our paper is the first that uses this methodology.

In the first part of our empirical analysis we use a quantity-based measure of financial integration exploiting a proprietary database from the Bank of International Settlements (BIS) that reports bilateral international bank assets and liabilities over the past three decades for a group of developed countries. $^{5}$ The extensive time dimension of the data allows us to account for fixed countrypair factors and global shocks (the first and second identification challenge). Our results show that accounting for these factors (and primarily for time-invariant country-pair characteristics) is fundamental. While in the cross section of country-pairs there is a significant positive correlation between banking integration and output synchronization, our panel estimates show that (within country-pair) increases in cross-border banking activities are followed by less synchronized, more divergent, output fluctuations. This result stands in contrast to previous empirical works that lacked high quality time-series bilateral data on cross-border financial linkages. While in line with theory that characterizes the correlation between financial integration and output synchronization in tranquil times when there are no major financial shocks, our findings contrast the conventional wisdom that financial globalization has lead to an increased synchronicity of economic activity even before the recent financial crisis.

\footnotetext{
${ }^{5}$ The literature on cross-border financial integration employs either de-facto (quantity and price based) or de-jure measures (see Adam, Jappelli, Menichini, Padula, and Pagano (2002) for a general discussion). De-facto indicators are typically outcomes, such as quantity of international bank or equity holdings (Lane and Milesi-Ferretti (2007)) or return correlation (Bekaert and Harvey (1995)). De-jure measures are based on the timing of stock market liberalization (Bekaert and Harvey (2000), Henry (2000)) or the removal of capital account restrictions (such as the widely used AREAER index of IMF).
} 
While the supervisory BIS data reflect more than $99 \%$ of the international exposure of the local banking system, they do not capture other forms of international investment (such as FDI and portfolio investment) between non-banks. Moreover, the BIS data (as most international capital data) miss-record investment channeled via off-shore financial centers. To account for these caveats (related to the fourth identification challenge), we construct a structural index of financial integration, which is based on the adoption timing of financial sector legislation that aims to harmonize the regulatory framework in financial intermediation across the European Union (EU) financial markets. Compared to outcome-based indicators (such as international capital holdings and return correlations), employing a time-varying de-jure measure of financial integration allows us to account for reverse causation arising from the fact that international banking may react to the synchronization of output fluctuations (the third identification challenge), while at the same time accounting for country-pair heterogeneity, global shocks, and common trends.

To construct the structural de-jure index of financial integration, we exploit in a quasi-natural experimental setting the peculiar nature of adopting EU-wide legislation across EU member countries - the EU Directives transposition system. The Financial Services Action Plan (FSAP) was a package of financial reforms launched by the EU in 1998 aiming to integrate the segmented EU financial markets and reduce the costs of cross-border financial intermediation. The FSAP included 29 major pieces of legislation (27 EU Directives and 2 EU Regulations) in banking, capital markets, corporate law, payment systems, and corporate governance. Examples include the Directive on money laundering, the Directive on financial collateral arrangements, the Directive on prospectuses, and the Directive on insider trading and market manipulation. In contrast to EU Regulations that become immediately enforceable across EU member countries, EU Directives are acts that become enforceable only after each EU member country passes domestic legislation adopting the EU Directive. The legal adoption of the EU Directive (the so-called "transposition" process) is notoriously slow, since it requires modifications of existing institutional structures, the removal of previous regulations and, in many cases, the establishment of new agencies and infrastructure. The transposition of the EU Directives takes in practice several years and differs considerably across EU member states. Using information from the EU Commission on the adoption timing of each of the Directives of the FSAP across EU countries, we construct a bilateral time-varying index that reflects how similar are the legal/regulatory structures governing the functioning of financial intermediation across each country-pair in each year.

Our panel estimates show that a higher degree of legislative/regulatory harmonization in financial services is associated with less synchronized output cycles. After showing that the simultaneous 
adoption of the EU-wide legislative acts by member countries are followed by strong increases in cross-border banking activities, we combine the structural index of financial integration based on legislative convergence in financial intermediation with the quantity-based banking integration measure (from the BIS) into a bilateral panel instrumental variables method. Our identification scheme builds on the insights of the law and finance literature showing that sound investor protection and legal quality lead to deep and efficient capital markets. ${ }^{6}$ It is also related to a new strand in corporate finance and law and economics literature that examines the effects of legal convergence on capital markets. ${ }^{7}$ Our identification method associates changes in the legal/regulatory environment governing financial intermediation that aim to harmonize segmented financial systems with changes in cross-border banking activities among countries that adopt the same piece of legislation and, in turn, with changes in output synchronization. The panel instrumental variable (IV) analysis reveals that the exogenous component of banking integration stemming from the harmonization of the regulatory environment in financial services makes business cycles less alike.

The paper is structured as follows. In the next section we detail the theoretical predictions of finance/banking models and international macro models. We also discuss previous empirical works. Section 3 describes our data. Section 4 reports and compares the cross-sectional and the panel estimates on the effect of cross-border banking integration on business cycle synchronization. In Section 5 we report panel estimates associating business cycle synchronization with a de-jure structural index of financial integration that reflects legislative/regulatory harmonization policies in banking, insurance, corporate law, and capital markets. Section 6 presents instrumental variable estimates associating legal convergence in financial services with banking integration (in the firststage) and output synchronization (in the second-stage). Section 7 decomposes bilateral banking activities into foreign assets and liabilities to further shed light on the theoretical mechanism. Section 8 concludes.

\section{Related Literature}

Theory makes opposing predictions about the effect of financial integration on international business cycle synchronization depending on the nature of the underlying shocks. In this section, we explain in detail the alternative theoretical channels modeled in the finance/banking and the international macro/finance literatures. We then go over previous empirical works.

\footnotetext{
${ }^{6}$ See La Porta et al. $(1997,1998)$ and La Porta, Lopez-de-Silanes, and Shleifer (2008).

${ }^{7}$ See, among others, Balas, La Porta, Lopez-de-Silanes, and Shleifer (2009), and Enriques and Volpin (2007), Christensen, Hail, and Leuz (2010) among others.
} 


\subsection{Theory: Financial Integration and Lower Synchronization}

Morgan, Rime, and Strahan (2004) develop a multi-economy variant of the canonical banking model of Holmstrom and Tirole (1997) and test it using cross-state banking exposure data across U.S. states. They show that if firms in certain states are hit by positive shocks that increase the value of their collateral, then under financial integration they receive more credit both from in-state and from out-of-state banks. As a result, output increases in the affected region relatively more as compared to output in other regions, making cycles to diverge. If a negative collateral shock hits one region (because productivity falls for example), then both local and out-of-state banks move away from the affected region, delivering the same asymmetry result for regional business cycles.

Working in an international context, Bekaert, Harvey, and Lundblad (2005) argue that if a country that liberalizes its equity markets has better growth opportunities than others (because for example its production is concentrated in high global demand sectors or because capital scarcity is associated with high returns), following a financial liberalization episode, capital will flow to that country and, therefore, output patterns between the two integrated countries will diverge (see also Bekaert, Harvey, Lundblad, and Siegel (2007)). By the same token, negative shocks will lead to capital withdrawals and thus output differences among financially integrated economies will get amplified.

International real business cycle theories model a similar mechanism that also yields a negative correlation between financial integration and output synchronization. In the workhorse dynamic general equilibrium framework of Backus, Kehoe, and Kydland (1992) with complete financial markets, the country hit by a positive productivity shock experiences an increase in the marginal product of capital and labor, workers increase their labor supply by decreasing time spent for leisure, and the country receives capital on net - a mechanism that leads to negative output correlations between the two countries.

In general equilibrium causality can also run in the other direction, from output divergence to financial integration. Heathcote and Perri (2004) show that a lower degree of output (and hence return) synchronization due to changing nature of shocks increases demand for diversification and, hence, increases bilateral financial integration via a higher volume of asset trade. KalemliOzcan, Reshef, Sørensen, and Yosha (2010) show that under full diversification of capital income, investment patterns are solely determined by relative productivities. Their model (and empirical results) suggests that capital will flow to the states with the highest productivity growth, creating even more divergent output growth patterns. 
A different mechanism linking financial integration and output synchronization based on industrial specialization was studied by Obstfeld (1994). In his model, financial integration shifts investment towards risky projects as it enables countries to specialize according to their comparative advantage; this implies that output growth among financially integrated countries should be negatively correlated. ${ }^{8}$

\subsection{Theory: Financial Integration and Higher Synchronization}

The model of Morgan, Rime, and Strahan (2004) also predicts that banking integration may lead to more, rather than less, synchronized output cycles. This occurs if the shock is on the banking sector rather than on firm's productivity/collateral. If there is a negative shock to banks' capital, the induced contraction of credit supply has negative real effects for the domestic economy. ${ }^{9}$ If the domestic credit supply reduction is significant, under banking integration, the business cycles of the two inter-connected regions/economies will become more synchronized, since banks that operate in financially inter-connected regions pull out funds from the non-affected region to continue lending in the affected region. Allen and Gale (2000) model this contagion-type mechanism through interconnected bank balance sheets; in their model shocks are transmitted through the interbank markets by banks from affected countries pulling out their international deposits and thus transmitting internationally the local shock. ${ }^{10}$

Dynamic stochastic general equilibrium models may also yield a positive (rather than a negative) relation between banking integration and business cycle synchronization (stemming from the feedback from interest rates to capital values). The early literature models this by introducing financial

\footnotetext{
${ }^{8}$ In line with this argument, Kalemli-Ozcan, Sørensen, and Yosha (2003) using regional-level data show that financial integration leads higher industrial specialization. Using country-level data Imbs (2004) and Kalemli-Ozcan, Sørensen, and Yosha (2001) show that higher industrial specialization leads to less synchronized cycles.

${ }^{9}$ Firms does not seem to be affected from the reduction in credit supply in developed countries as shown by Rice and Strahan (2010) for U.S. and Jimenez, Mian, Peydro and Saurina (2010) for Spain in general. In the current crisis there is also a reduction in credit supply as shown by Jimenez, Ongena, Peydro and Saurina (forthcoming) and Puri, Rocholl and Steffen (2011), but again there is no obvious evidence on the real effects of such reductions. In developing countries, in contrast, credit supply contractions may be more binding for firms, as shown, for example, by Paravisini (2008) for Argentina; Khwaja and Mian (2008) for Pakistan, Paravisini, Rappoport, Schnabl, and Wolfenzon (2010) for Peru; and Kalemli-Ozcan, Kamil, and Villegas-Sanchez (2010) for 6 Latin American countries. The last two papers show real effects in terms of declining exports (Peru) and declining investment (6 Latin American countries) of firms. In a global financial crisis, such as the $2007-2009$ one, even developed country firms may suffer from credit supply shocks (see, for example, Ivashina and Scharfstein (2010) and Cornett, McNutt, Tehranian, and Strahan (2011) for U.S., Maddaloni and Peydro (2011) for the euro area and U.S.).

${ }^{10}$ Rochet and Tirole (1996) and Freixas, Parigi and Rochet (2000) also model interbank contagion. While in the latter and second papers the effects are through balance-sheet pecuniary externalities among banks as in Allen and Gale (2000), in the first paper financial contagion comes through peer (interbank) bad monitoring. Iyer and Peydro (2011) test these interbank contagion models.
} 
frictions into the standard international real business cycle model (with productivity/technology shocks), that stop or reverse the direction of capital flows (Calvo and Mendoza (2000)), or leveraged and constrained firms liquidate and run down asset prices when they got hit by a negative shock to their capital (Devereux and Yetman (2009)). ${ }^{11}$ The recent literature introduces banking shocks in addition to productivity shocks (e.g. Perri and Quadrini (2010); Mendoza and Quadrini (2010); Enders, Kollmann, and Muller (2010), Kalemli-Ozcan, Papaioannou and Perri (2012)). In these models, banks and/or firms have collateral constraints. When there is a negative shock to the banking sector in the domestic economy, banks cut their lending globally since their net worth goes down and they have to shrink their balance sheet. Foreign banks from non-affected countries stop lending to firms in the affected economy due to limited enforcement of debt contracts that increases the cost of default in bad times. As a result of the drop in asset prices, the initial shock to domestic banks' balance sheet spreads internationally. Hence, foreign banks' net worth also falls and as such they also need to shrink their balance sheet. This, in turn, leads to rising financing costs in both financially integrated countries. All these mechanisms reinforce each other and lead to a higher synchronization of economic activity between financially integrated countries.

\subsection{Empirical Evidence}

Independently of the period, country and empirical method used, almost all empirical studies document a positive correlation between financial integration and GDP co-movement. ${ }^{12}$ Using cross-country data over a long period, Kose, Prasad, and Terrones (2003) find that financially open countries without capital account restrictions have more synchronized business cycles with world output. Imbs (2006) uses bilateral (country-pair) data on equity and debt holdings constructed by the IMF on a large cross-section of countries and shows a significant positive correlation between bilateral portfolio holdings and output synchronization. Similarly Otto, Voss and Willard (2001) find that OECD countries with strong FDI linkages have more similar cycles. ${ }^{13}$ While examining the cross-sectional data patterns is the natural first thing to do, these type of cross-sectional correlations though informative do not identify causal effects, as they might be driven by common

\footnotetext{
${ }^{11}$ See Brunnermeier, Eisenbach, and Sannikov (2011) and Pavlova and Rigobon (2011) for surveys of the literature on international macroeconomics with financial frictions,.

${ }^{12}$ For the broader literature that quantifies the effects of financial integration on economic growth, output volatility, and risk sharing, see Bekaert, Harvey and Lundblad (2005, 2006, 2011); Bekaert, Harvey, Lundblad, Siegel (2007); Henry (2000); Prasad, Kose, Rogoff, and Wei (2009); Kalemli-Ozcan, Sørensen and Volosovych (2010).

${ }^{13}$ The only study to our knowledge that documents a negative association between financial integration and synchronization is Garcia-Herrero and Ruiz (2008). These authors use capital account data for Spain and document a lower GDP synchronization of Spain with countries that Spain has strong financial linkages.
} 
global shocks and/or unobserved country-pair heterogeneity. Another problem with most previous works is that they pool developed, emerging, and under-developed countries in the estimation. Theoretically this is not ideal, as these countries have experienced different types of shocks in the past three decades (for example, industrial countries did not experience major financial crises till 2007, while emerging and underdeveloped economies experienced many currency and banking crises over the past decades). Moreover, parallel work examining the effects of trade integration on business cycle synchronization suggests that there are fundamental differences between advanced and emerging/underdeveloped countries (Kraay and Ventura (2000, 2007); Calderon, Chong, and Stein (2007)).

Morgan, Rime, Strahan (2004) show that banking deregulation in the U.S. over the late 1970s and early 1980s dampened economic volatility and made state business cycles more alike. They interpret their findings as suggesting that bank capital supply shocks were the dominant source of output fluctuations during this period in the U.S. Our results are in contrast to those of Morgan, Rime, Strahan (2004). We think the difference is due to our sample of developed European countries which under all accounts did not experience major credit supply shocks (with the exception of Scandinavian banking crisis) during our period of study, $1978-2006$.

A few papers focused empirically on the international transmission of a shock and contagion via financial linkages. Kaminsky, Reinhart, and Vegh (2003) find that contagion episodes involve a leveraged common creditor, and hence contagion happens through balance sheets of financial intermediaries, a channel originally proposed by Calvo (1998). Peek and Rosengren (2000), for example, study the transmission of the Japanese crisis to the U.S. by investigating the real estate activity in the U.S. states where Japanese banks are present.

Kaminsky and Reinhart (2000) focus on the role played by commercial banks in spreading shocks by cutting bank lending during the debt crisis of 1982 and the crisis in Asia in 1997. Likewise Van Rijckeghem and Weder (2003) document that the Latin American and the East Asian countries were spread internationally via banking linkages. Similarly, Schnabl (2011) studies the effect of 1998 Russian default on international bank lending in Peru. He finds a stronger transmission effect for the domestic Peruvian banks that borrow internationally compared to foreign-owned banks, who mitigate the effect of a shock through better risk management. Focusing on the recent crisis, Cetorelli and Goldberg (2011) find that credit supply in emerging markets was affected through a contraction in cross-border lending by foreign banks; a contraction in local lending by foreign banks' affiliates in emerging markets; and a contraction in lending supply by domestic banks due to a funding shock to their balance-sheet. Ongena, Peydro and van Horen (2012) using detail firm-, 
bank- and bank-firm- level data find that foreign ownership and liquidity transmitted the recent crisis to the Eastern and Central Europe countries. In contrast, Rose and Spiegel (2010) and Lane and Milesi-Ferretti (2011) did not find any role of financial linkages, in general, in transmitting the crisis of $2007-2009$.

Most papers in finance examine whether equity or debt return correlations increase after a financial shock (see for example Forbes and Rigobon (2002) and Bekaert, Harvey, and Ng (2005)). Frankel and Schmukler (1998) and Kaminsky, Lyons, and Schmukler (2001, 2004) show evidence for U.S. based mutual funds spreading shocks throughout Latin America by selling assets from one country when prices fall in another (especially in the case of Mexico peso crisis). A similar finding is shown by Jotikasthira, Lundblad, and Ramadorai (2009), who provide evidence on the importance of global fund flows in driving up emerging market returns. Bartram, Griffin, and Ng (2010) find a strong effect of foreign ownership linkages on the correlation of international stock returns. Their results are mainly for developed countries.

\section{Data}

\subsection{Banking Integration}

Our banking integration data come from the confidential version of BIS International Locational Banking Statistics Database. This database reports asset and liability holdings of banks located in roughly forty (mainly industrial) countries ("the reporting area") in more than one hundred and fifty countries (the "vis-a-vis area") at a quarterly frequency since the end of 1977 . Yet, half of the "reporting area" countries started providing data to the BIS only recently (mostly after 2000). Thus our panel dataset consists of annual bilateral (country-pair) data from and to eighteen rich economies over the period 1978-2006. ${ }^{14}$ These countries are: Australia, Austria, Belgium, Canada, Switzerland, Germany, Denmark, Spain, Finland, France, United Kingdom, Ireland, Italy, Japan, Netherlands, Portugal, Sweden, and the United States. ${ }^{15}$

The data is originally collected from domestic monetary authorities and local supervisory agen-

\footnotetext{
${ }^{14}$ We prefer to use annual data given the noisy nature of quarterly data (though this has no effect on our results). Cross-border capital (or trade) flows data usually have gaps that make logarithmic transformations questionable. This is not the case in our data. There are only a few missing observations, mainly in the initial years (as some countries like Spain and Finland start reporting in 1983).

${ }^{15}$ In the previous version of the paper we also included Luxemburg and Greece. We dropped Luxemburg because the international position of banks in and from Luxemburg is extremely high. We also dropped Greece because data become available only after 2003. Including these countries does not affect our results.
} 
cies, which pass the data to the BIS which in turn performs a series of consistency checks to construct the database. The supervisory data include all of banks' on-balance sheet exposure and reflect more than $99 \%$ of the overall international exposure of a country's banking institutions. The data mainly captures international bank to bank debt holdings, such as inter-bank credit lines, loans and deposits. Assets include deposits and balances placed with non-resident banks, including bank's own related offices abroad. They also include holdings of securities and participations (i.e. permanent holdings of financial interest in other undertakings) in non-resident entities. Data also include trade-related credit, arrears of interest and principal that have not been written down and holdings of banks own issues of international securities. The data also cover bank's investment in equity-like instruments as well as foreign corporate and government bonds.

The BIS dataset does not distinguish between inter-bank debt activities and portfolio equity investment. Yet the data mainly reflect holdings of debt-like financial instruments. BIS (2003a,b) and Wooldridge (2002) argue that while FDI and equity have become more important after the late nineties, their weight is still small as standard banking activities still consist the bulk of crossborder holdings. International bank M\&A activity and direct lending to foreign residents have been limited overall (see Lane and Milesi-Ferretti (2008)). According to our calculations based on the unilateral (at the country-time level) data of Lane and Milesi-Ferretti, debt holdings reflect $67 \%$ of the total foreign positions between 1978 - 2006 for our group of countries; with equity and FDI jointly account for a third of total foreign investment. Banking activities in particular account for half $(48.5 \%)$ of total foreign holdings and flows in 2006. For most of the 28 year period they accounted for around $60 \%$ (and in the early years for almost $80 \%$ ) of total international holdings.

The BIS data is expressed originally in current US dollars. We convert the data into constant US dollars by deflating the series with the U.S. consumer price index (CPI). Following previous works we use the total stock of external assets and liabilities and construct two quantity-based measures of financial integration. The first measure (BANKINT1) is the average value of (the logs of) real bilateral asset and liability holdings normalized with the sum of the population of the two countries. The second measure $(B A N K I N T 2)$ is the average of (the logs of) real bilateral asset and liability holdings as a share of the two countries' GDP. ${ }^{16}$

\footnotetext{
${ }^{16}$ In the previous version of the paper we experiment with other proxy measures of financial integration, using transactions data. The results are similar. We report data based on holdings (rather than transactions) because theory and previous empirical works focus on the outstanding stock of international investors (banks in our application).
} 


\subsection{Output Synchronization}

We construct three different measures of business cycle synchronization $\left(S Y N C H_{i, j, t}\right)$ using GDP data from the latest update of World Bank's World Development Indicator's Database (WB WDI 2010). First, following Giannone, Lenza, and Reichlin (2008), we measure business cycle synchronization with the negative of divergence, defined as the absolute value of real GDP growth differences between country $i$ and $j$ in year $t$.

$$
S Y N C H 1_{i, j, t} \equiv-\left|\left(\ln Y_{i, t}-\ln Y_{i, t-1}\right)-\left(\ln Y_{j, t}-\ln Y_{j, t-1}\right)\right|
$$

Second, we follow Morgan, Rime, and Strahan (2004) and construct $S Y N C H 2_{i, j, t}$ as follows. We regress in the beginning real GDP growth for country $i$ and country $j$ on country fixed-effects and year fixed-effects.

$$
\ln Y_{i, t}-\ln Y_{i, t-1}=\gamma_{i}+\phi_{t}+v_{i, t} \forall i, j
$$

The residuals for these regressions $\left(v_{i, t}\right.$ and $\left.v_{j, t}\right)$ reflect how much GDP growth differs in each country and each year compared to average growth in this year and the average growth of this country over the estimation period. We then construct the business cycle synchronization proxy as the negative of the absolute difference of residual GDP growth:

$$
S Y N C H 2_{i, j, t} \equiv-\left|\nu_{i, t}-\nu_{j, t}\right|
$$

Intuitively this index measures how similar GDP growth rates are between two countries in any given year, accounting for the average growth in each country and the average growth in each year.

These two indicators are simple and intuitive. In contrast to the correlation measures that cross-country studies mainly work with, the above indices are not sensitive to the various filtering methods that have been criticized on many grounds (e.g. Canova $(1998,1999)$ ). They also do not contain estimation error that emerges, for example, from self-selecting a rolling estimating window. Again differently from the correlation measure, these indices do not directly reflect the volatility of output growth. Doyle and Faust (2005) underline the importance of a synchronization measure that (ideally) does not include volatility. Isolating the covariance part is desirable, because, over the past two decades, global output volatility has fallen considerably in the industrial economies (e.g. Cecchetti, Flores-Lagunes, and Krause (2006)). Nevertheless, for comparison purposes with 
previous cross-country studies, we also report specifications with the correlation of the cyclical component of output as measured with Baxter and King (1999) Band-Pass filter $\left(2,8 ; S Y N C H 3_{i, j, t}\right)$ (e.g. Imbs (2006); Baxter and Kouparitsas (2005)).

\subsection{Descriptive Statistics}

Table 1-Panel $A$ reports descriptive statistics for the main variables employed in the empirical analysis. To illustrate the within country-pair time variability and the cross-sectional variability, we report in Panel $B$ summary statistics conditioning on country-pair fixed-effects and in Panel $C$ descriptive statistics conditioning on time (year) fixed-effects. The average divergence in real GDP growth over the sample period is $1.78 \%$ ( $S Y N C H 1$ ). Once we control for country and year fixedeffects ( $S Y N C H 2)$ the differences are somewhat smaller (mean of $1.56 \%$ ). Both synchronization indicators exhibit significant variation both across country-pairs and within country-pairs over time (the standard deviation is $1.5 \%$ and $1.41 \%$ respectively).

Figure 1 gives a graphical illustration on the evolution of the average (across country-pairs) value of the three measures of business cycle synchronization over the 28 years of our examination. Growth divergence measures, $S Y N C H 1$ and $S Y N C H 2$, are plotted on the left $y$-axis; the correlation measure, $S Y N C H 3$, is tabulated on the right $y$-axis. There is a considerable degree of short-term variability, which is quite useful in our empirical exercise. Overall output synchronization has been steadily increasing according to all measures since the mid-1980s (see also Kose, Otrok, and Prasad (2008) and Rose (2009)). The average correlation of the cyclical component of GDP (SYNCH3) was around $0.1-0.3$ in the $1980 \mathrm{~s}$. In the $1990 \mathrm{~s}$ the correlation increased on average to 0.4 , while in the 2000s the correlation reached $0.6-0.7$, before falling to around 0.5 before the $2007-2009$ financial crisis. Likewise, average differences in real GDP growth in the late 1970s and the 1980s were in the range of $2.5 \%-3.5 \%$, while after the late 1990 s the average difference fell to $1 \%-1.5 \%$.

Figure 2 plots the evolution of cross-border banking holdings in the period $1978-2006$. Crossborder bank holdings have increased dramatically over the past three decades. Lane and MilesiFerretti (2007) document similar patterns for other types of cross-border investment flows, such as FDI and equity. Yet international banking activities are by far the largest component of foreign capital holdings/flows. Figure 2 shows that real international bilateral bank holdings (per capita) have increased from an average value (across the 153 country-pairs of our sample) of roughly 170 dollars to almost 1,600 dollars per person as of the end of 2006. 


\section{Banking Integration and Business Cycle Synchronization}

\subsection{Econometric Specification}

We start our analysis estimating with OLS variants of the following specification:

$$
S Y N C H_{i, j, t}=\alpha_{i, j}+\alpha_{t}+\beta B A N K I N T_{i, j, t-1}+\mathbf{X}_{i, j, t-1}^{\prime} \Psi+\varepsilon_{i, j, t}
$$

$S Y N C H_{i, j, t}$ reflects the co-movement of output as reflected in the three synchronization measures between countries $i$ and $j$ in period $t$. BANKINT $T_{i, j, t-1}$ is one of our two measures of crossborder banking integration between countries $i$ and $j$ in the previous year/period $(t-1) .{ }^{17}$ The specification includes year/time $\left(\alpha_{t}\right)$ and country pair fixed-effects $\left(\alpha_{i, j}\right)$. The year/time fixedeffects account for the effect of global shocks and other common time-varying factors that affect both business cycle patterns and banking integration. The year fixed-effects also account in a flexible non-parametric way for the overall fall in output volatility over our sample period. The countrypair effects account for hard-to-measure factors such as cultural ties and similarities, informational frictions, and other time-invariant unobservable factors, all of which have been shown to have an effect on both financial integration and business cycle patterns. Vector $\mathbf{X}_{i, j, t-1}^{\prime}$ captures other country-pair time-varying factors that may affect the dynamic evolution of output synchronization, such as "gravity" measures (GDP and population), trade, specialization, time trends.

\subsection{Cross-Sectional Estimates}

Table 2 presents cross-sectional and panel fixed-effects estimates on the effect of banking integration on GDP synchronization. For comparability with previous studies analyzing the correlation between financial integration and output synchronization, we start our analysis in Panel $A$ estimating crosssectional models that pool the time series observations across all country pairs. The "between" estimator removes the time dimension by averaging the dependent and the explanatory variable across country-pairs. Thus for these models we have a single observation for each country-pair.

Columns (1)-(4) report cross-sectional estimates using synchronization in GDP growth rates ( $S Y N C H 1$ and $S Y N C H 2$ ) as the dependent variable. The cross-sectional coefficient on the two banking integration measures is positive and significant at the $99 \%$ confidence level, a result in

\footnotetext{
${ }^{17}$ We use lagged values to partly account for reverse causation. We also estimated specifications using contemporaneous values of financial/banking integration finding similar (and if anything stronger) results. We formally deal with reverse causation and other forms of endogeneity in sections 5 and 6 .
} 
line with previous cross-country works (e.g. Imbs (2006)). The estimates imply that across the 153 pairs of industrial countries, there is higher covariation of GDP growth among economies with stronger financial ties.

Columns (5)-(8) report estimates using the cyclical component of GDP (SYNCH3) estimated over a 5-year period as the dependent variable. These models are estimated in six non-overlapping 5 -year periods. The unconditional coefficients on banking integration reported in (5) and (7) are positive and highly significant; this implies that countries with stronger financial linkages have more correlated output cycles. In columns (6) and (8) we examine whether our results reflect differences on trade intensity and industrial specialization. Following Calderon et al. (2007) we control for differences in trade intensity using the log of bilateral real (deflated with the U.S. price deflator) exports and imports as a share of the two countries' GDP. Following Krugman (1991) and Kalemli-Ozcan, Sørensen and Yosha (2003) we measure specialization with an index that reflects how dissimilar industrial production is in manufacturing $\left(S P E C_{i, j, t} \equiv \sum_{n=1}^{N}\left|s_{i, t}^{n}-s_{j, t}^{n}\right|\right.$, where $s_{i, t}^{n}$ and $s_{j, t}^{n}$ denote the GDP share of manufacturing industry $n$ in year $t$ in country $i$ and $j$ respectively). A priori it looks important to account for differences in bilateral trade when working with longterm data as trade in goods and financial services tend to move in tandem (e.g. Rose and Spiegel (2004)) and previous studies show that trade has a significantly positive effect on business cycle synchronization (e.g. Frankel and Rose (1998)). Likewise accounting for specialization patterns seems important as financial integration affects specialization patterns and vice versa (e.g. Obstfeld (1994); Kalemli-Ozcan, Sørensen, and Yosha (2001)). In line with previous studies, trade enters with a positive estimate. The regressions further show that countries with dissimilar production structures have less synchronized cycles; yet this effect is not statistically significant, most likely because of the limited variability of the specialization index over a 5 -year horizon. Most importantly for our focus, the estimate on BANKINT continues to be at least two standard errors above zero in both permutations. ${ }^{18}$

\subsection{Panel Fixed-Effect Estimates}

In Table 2, Panel $B$ we report otherwise identical to Panel $A$ specifications, but we add countrypair fixed-effects and time fixed-effects in the empirical model (as shown in equation (3)). Due to serial correlation, standard errors in the panel models in Panel $B$ (and all subsequent tables)

\footnotetext{
${ }^{18}$ When we control for trade intensity and differences in industrial specialization we lose roughly $35 \%$ of our sample due to data unavailability on the industrial statistics needed to construct SPEC. We thus also augmented the empirical model with trade and specialization one at a time, obtaining similar results.
} 
are clustered at the country-pair level (Bertrand, Duflo, and Mullainathan (2004)). This method allows for arbitrary heteroskedasticity and autocorrelation for each country pair. ${ }^{19}$ The panel estimates (in Panel $B$ ) stand in contrast to the cross-sectional coefficients (in Panel $A$ ). In all perturbations with the annual data reported in (1)-(4) the estimate on banking integration enters with the opposite sign to the cross-sectional specifications. The panel fixed-effect models thus imply that a higher level of international banking integration is associated with a lower degree of output synchronization. This result is present with both banking integration measures and both synchronization indicators. In columns (5)-(8) we estimate panel fixed-effects models using the correlation of the cyclical component of GDP estimated over 5 non-overlapping five-year periods as the dependent variable. Again there is a sharp difference between the cross-sectional and the within country-pair estimates. The estimates in columns (6) and (8) show that this result is not driven by changes on goods' trade and changes on industrial structure.

As a result, while in the cross-section there is a positive association between output co-movement and financial integration, as financial linkages become stronger within country-pairs over time output growth rates diverge. (Appendix Figures 1 and 2 give a graphical illustration of the sharp differences in the correlation between financial integration and output synchronicity). The striking difference between the cross-sectional and the panel estimates suggests that omitted variable bias arising from common global time-varying shocks and hard-to-account-for country-pair characteristics was plaguing estimates in previous cross-sectional studies.

\subsection{Further Evidence and Sensitivity Analysis}

In Appendix Table 1 we explore the underlying reasons behind the sharp difference in cross-sectional and within country-pair correlation between financial integration and output synchronization. In Panel $A$ we report specifications adding only year constants. In all permutations the coefficient on banking integration is positive and highly significant, implying that solely accounting for common to all countries shocks does not suffice to switch the sign of the estimate. Yet the coefficients on banking integration drop by half as compared to the analogous estimates (in columns (1)-(4) of Panel $A$ - Table 2), where we were not conditioning on time fixed-effects. This shows that accounting for common global factors is economically important. In Panel $B$ we condition on country-pair fixed-effects to explore the within panel variation. To account for the upward trend and the non-

\footnotetext{
${ }^{19}$ Newey-West standard errors that allow for common across country-pairs auto-correlation are similar (and if anything somewhat smaller) compared to clustered at the country-pair dimension standard errors. We also estimated standard errors with the multi-way clustering method of Cameron, Gelbach, and Miller (2011) clustering at the year $t$, at country $i$ and at country $j$ dimensions, finding similar results.
} 
stationary nature of banking integration (see Figure 2), we simply add a single (common to all countries) linear time trend. The coefficient on banking integration turns negative. This suggests that accounting for hard-to-observe country-pair fixed factors is fundamental. While in the cross-section there is a strong positive correlation between output synchronization and banking integration, within country-pair increases in banking activities are followed with less synchronized output cycles. In Panel $C$ and Panel $D$ we account for unobserved dynamics including in the empirical specification country-specific time trends and country-pair specific time trends, respectively. In Panels $E$ and $F$ we also include time (year) fixed-effects (on top of the country and the country-pair specific time trends). Across all model permutations the banking integration measures enter with highly significant negative coefficients.

A potential drawback of the results in Table 2 columns (5)-(8) is that the correlation measure (SYNCH3) is estimated over a short (five-year) period. Thus we re-estimated the specifications splitting the sample into two periods and used as the dependent variable the correlation of the cyclical component of GDP estimated over each 14-year period. Appendix Table 2 reports the results. Panel $A$ gives cross-sectional estimates while Panel $B$ reports country-pair fixed effects estimates with a period constant (i.e. time effect). The panel estimate on banking integration in the beginning of each of the two 14-year periods is negative and statistically different than zero at the $1 \%$ level. The long-run analysis therefore also points out that increases in cross-border banking activities have been associated with less synchronized output cycles.

In Table 3 we examine whether the significantly negative within country-pair association between output synchronization and banking integration is driven by other factors. In column (1) we control for the two usual "gravity" variables reflecting size, namely the log of the product of the two countries' GDP in the previous year and the log of the product of the two countries population in the previous year. ${ }^{20}$ By conditioning on the product of GDP, we account for the possibility that our estimates are driven by countries receiving a lot of foreign bank capital and at the same time converging to a new steady state. Including the GDP we also account for the cyclical properties of international business cycle synchronization. The coefficient on banking integration falls somewhat compared to the analogous estimate in column (1) of Table 2-Panel B, from 0.385 to 0.275 . Yet the estimate is more than four standard errors below zero.

In columns (2) and (3) we include in the empirical specification the lagged value of the absolute

\footnotetext{
${ }^{20}$ Including GDP and population for country $i$ and country $j$ separately (i.e. not taking the product) yields almost identical estimates. The factors capturing proximity, such as geographic distance, cultural ties, genetic similarities are absorbed by the country-pair fixed-effects.
} 
difference in the log per capita GDP. By doing so we control for the possibility that the negative effect of banking integration on output growth synchronization is simply driven by the fact that financial integration increases among dissimilar (in terms of income per capita) countries, which may also experience different growth patterns since poor country will grow faster then the rich. Relatively low income countries, might experience an increase in their banking integration since international banks (from rich economies) chase higher returns in capital scarce countries. The negative within country-pair association between banking integration and output synchronization remains intact. In columns (4) and (5) we condition on the lagged value of the absolute value of the difference in bilateral trade, to control for the possibility that the significant negative association between banking integration and output synchronization operates via goods trade. The estimate on the difference in goods trade is statistically indistinguishable from zero, while the coefficient on banking integration is highly significant. Thus there is no evidence that banking integration leads to output divergence by amplifying trade imbalances.

One may be worried that the significant negative association between output synchronization and banking integration is driven by hard-to-measure country (or even country-pair) dynamics. For example the adoption of the euro may have changed the dynamics of output growth and financial integration well before its introduction in 1999. To account for this type of concerns in columns (6) and (7) we include in the empirical specification country-specific and country-pair specific linear time trends, respectively. This has no major effect. Increases in banking integration are followed by divergent output cycles, even when we condition on country-pair specific time trends.

We performed additional sensitivity checks to investigate the stability of our OLS estimates that reveal a striking difference between the cross-sectional and the over time within country-pair correlation of banking integration and output synchronization. Among others, we checked whether our results are driven by influential observations. The change in the sign of the coefficient on banking integration is not due to any particular country-year observations. We also estimated a weighted least square (WLS) by population and GDP regression to guard against the influence of small country pairs, obtaining similar results. We also used unstandardized measures of banking integration and controlled directly for population and/or GDP, again finding similar results. In the previous version of the paper we also estimated auto-regressive specifications, controlling for inertia in business cycle synchronization (though differences in GDP fluctuations are not particularly persistent; the first auto-regressive coefficient is around 0.15). Again the results are similar. 


\section{$5 \quad$ Financial Sector Legislative-Regulatory Harmonization and Out- put Synchronization}

Our results in Table 2-Panel $B$ and Table 3 show a strong negative effect of banking integration on business cycle synchronization in a panel of industrialized countries. Although this result is robust to a variety of sensitivity checks, the OLS coefficients do not capture the one-way effect of financial integration on output synchronization.

A first concern emerges from potential omitted variables. Most of the robust correlates of business cycle synchronization are time-invariant and, hence, our country-pair fixed-effects account for these factors (Baxter and Kouparitsas (2004)). Inclusion of time effects also mitigates concerns that our estimates are driven as a result of a common shock. Moreover the results are not driven by unobserved country or even country-pair specific trends in the dynamics of output synchronicity and banking integration. Nevertheless, we cannot completely rule out that an omitted time-varying country-pair factor may affect both output synchronization and banking integration.

Second, there is the possibility of reverse causation. This type of endogeneity may arise if banking integration is the outcome rather than the cause of business cycle divergence. To partly account for this possibility, in our panel estimates we have used lagged values of banking integration (and the other controls). Given the low persistence of output co-movement, employing lagged values seems reasonable. Yet, clearly it is not ideal.

Third, there are worries that measurement error may affect the LS estimates. The supervisory nature of the BIS data that capture all cross-border banking activities, implies that classical errorin-variables is negligible. Yet the BIS data do not include other types of international investment, such as portfolio investment by non-banks and FDI (see for example Bartram, Griffin and Ng (2010) and Jotikasthira, Lundblad and Ramadorai (2011) for recent studies exploring the effect of foreign ownership and mutual fund holdings in the international transmission of shocks). Since there is a high correlation between equity flows and debt flows, this concern is not severe in our context. ${ }^{21}$ A probably more important problem is that our data (as most data on cross-country investment that are based on the "residence" principle) miss banking activities channeled via small off-shore

\footnotetext{
${ }^{21}$ According to the latest vintage of the Lane and Milesi-Ferretti dataset of aggregate (at the country-level) foreign holdings, the correlation of total debt, portfolio debt, banking, FDI and equity in levels (either expressed as a share of total assets or as a share of GDP) is the range of $0.75-0.99$. In first differences the correlation weakens, but is always larger than 0.50. Country-pair datasets on foreign capital holdings also suggest a strong correlation of the various types of international investment. For example, Kubelec and Sa (2009) document that the correlation between our BIS data and CPIS bilateral debt data, which has a broader coverage of debt assets and liabilities, is $80 \%$.
} 
financial centers. Below, we construct an exogenous structural index of financial integration that reflects regulatory/legislative harmonization reforms in financial services across Europe that allows to account for these concerns.

\subsection{De-jure measure of financial integration}

We construct a structural measure of financial integration using data on financial sector harmonization policies across EU15 countries on the implementation of the legislative acts of the Financial Services Action Plan (FSAP). The FSAP was a major policy initiative launched in 1998 by the EU Commission and the EU Council (the two main bodies of the European Union) that aimed to remove regulatory and legislative barriers across European countries in financial intermediation. Besides technical recommendations and communications, the FSAP included 29 major pieces of legislation, 27 EU Directives and 2 EU Regulations. The FSAP included legislation on securities markets (e.g. the Prospectus Directive and the Directive on Insider Trading), corporate governance (e.g. the Transparency Directive and the Takeover Bids Directive), banking (e.g. Directive on Capital Adequacy), and insurance (e.g. the Solvency Directive), among others. ${ }^{22}$ Until the official completion date at the end of 2003 the EU Commission had passed 21 of these measures. The remaining 6 Directives of the FSAP passed in the period $2004-2006$.

In contrast to EU Regulations that become instantly part of the legal order of all EU member countries, EU Directives are legal acts that do not become immediately enforceable across the EU. Instead, member countries are given time to adopt, modify, and eventually transpose the EU Directives into domestic law. As with other pieces of EU-initiated legislation, there is a great deal of heterogeneity on the speed with which European countries adopted the FSAP Directives (see Supplementary Appendix Tables $A$ and $B$ ). The time of the transposition/adoption of EU Directives takes many years, as EU member states delay the adaptation for various reasons, such as parliamentary delays, because new agencies need to be established, existing laws be removed, and due to many other technical obstacles. Moreover member states may delay to adopt the EU law to shield domestic firms from foreign competition and other political considerations. For example, in our context only four EU countries (Denmark, France, Finland and the UK) transposed into the domestic legal order the "Directive on the Supervision of Credit Institutions, Insurance Undertakings and Investment Firms in a Financial Conglomerate" within the first two years since its circulation (in November 2002) by the EU Commission. Instead, it took five years for the

\footnotetext{
${ }^{22}$ Malcom et al. (2009) and Enriques and Gatti (2008) give details on the FSAP and the transposition of EU financial legislation into national law.
} 
Netherlands and Sweden to adopt this important piece of financial legislation, while one country (Portugal) had not transposed the Directive till the end of our sample period.

We use the transposition timing across member states to construct a time-varying structural measure of financial integration for each country-pair. We construct the bilateral legislativeregulatory harmonization index as follows: First, we define 27 indicator variables $\left(L E X_{i, j, t}^{k}\right.$, one for each FSAP Directive $k$ ) that equal one if at any given year both countries in each country-pair cell have transposed each EU Directive into national law, and zero otherwise. Second, we create a country-pair time-varying legislative harmonization measure by summing the values of these 27 indicator variables $\left(L E X_{i, j, t}^{k}\right)$. Since the variable is highly skewed in the regressions we use the $\log$ value, adding 1, i.e., $H A R M O N_{i, j, t} \equiv \ln \left(\sum_{k=1}^{K=27}\left(1+L E X_{i, j, t}^{k}\right)\right)$.

The legislative/regulatory harmonization index reflects how similar are the structures governing financial intermediation among EU member countries. Thus one could think of this measure as a de-jure index of financial integration, similar in spirit to cross-country integration measures based on the removal of capital account restrictions (e.g. Quinn (2003)) and the liberalization of equity market investment (e.g. Bekaert, Harvey, and Lundblad (2005)). The harmonization index in financial services is also similar in spirit to measures dating banking deregulation policies across U.S. states (e.g. Jayarante and Strahan (1997)). Yet in contrast to these works that produce country (or state) level indicators of financial integration, the harmonization index we construct exhibits within country-pair across-time variation as it reflects the situation when two countries have adopted the exact same regulatory legislation in financial intermediation.

\subsection{Harmonization in Financial Intermediation and Business Cycle Synchro- nization}

In Table 4 we examine the effect of legislative-regulatory harmonization policies in financial services on output synchronization. The estimate on $H A R M O N_{i, j, t-1}$ in column (1) is negative and highly significant. This suggests that conditional on time-invariant country-pair factors and common to all countries time-varying factors, harmonization policies in financial services have lead to a lower degree of output growth co-movement. This result is in line with our previous estimates that revealed a strong negative within country-pair association between output synchronization and the quantity measure of banking integration.

In column (2) we control for bilateral differences in the exchange rate regime. This is important as there is the possibility that the legislative/regulatory harmonization index in financial services 
captures (partly at least) the effect of monetary unification that occurred around the same time as the launch of the FSAP. To do so we exploit the update of the de-facto exchange rate regime classification of Reinhart and Rogoff (2004) by Ilzetzki, Reinhart, and Rogoff (2008). The Reinhart and Rogoff "coarse" classification ranges from 1 to 5 where lower values suggest a more rigid regime. For example, euro area countries get a score of 1 after 1999 and a score of 2 in the 1990s, when they were participating in the European Exchange Rate Mechanism. Using this dataset we construct a bilateral time-varying exchange rate regime index by taking the sum of the log classification of countries $i$ and $j$ in the beginning of each year $t\left(E R C=\ln \left(E R_{i, t}\right)+\ln \left(E R_{j, t}\right)\right)$. The exchange rate flexibility index enters with an insignificant estimate (not reported), while the structural index of financial integration that reflects regulatory-legislative harmonization policies in financial services ( $H A R M O N)$ continues to enter with a highly significant negative coefficient.

In column (3) we control for the lagged values of the log of the product of the two countries' GDP, the log of the two countries' population, and the absolute value of the difference in log per capita GDP (that all entered with significant estimates in Table 3). This has little effect on our main result. The coefficient on the structural index of financial integration continues to be negative and more than two standard errors below zero.

In columns (4) and (5) we include country-specific and country-pair specific linear time trends, respectively. The bilateral regulatory/legislative harmonization index in financial services continues to enter with a negative and significant estimate. The estimate is quite similar to the coefficient in the more parsimonious specifications in columns (1) and (2) suggesting that accounting for differential convergence paths, the nature of the exchange rate regime, and unobserved dynamics has no major effect on our main result.

To further account for the potential confounding effect of European Monetary Union (EMU) in column (6) we augment the specification with two dummy variables that take on the value one when one of the two countries is a member of the EU or the euro area in each year and zero otherwise; and two indicators that switch to one when both countries are members of the EU or the euro area (and zero otherwise). The coefficient on legal-regulatory integration in financial services retains its economic and statistical significance.

One may be worried that the highly significant effect of legislative/regulatory harmonization policies on output synchronization is driven by hard-to-account-for factors distinguishing the recent period of financial globalization with the eighties where cross-border capital flows were small. Thus, in columns (7)-(12) we report otherwise similar to columns (1)-(6) specifications focusing only in 
the period 1995 - 2006. While we lose efficiency, in all permutations the structural measure of financial integration enters with a highly significant negative coefficient.

The quantitative impact of these estimates is significant. For one standard deviation increase in our harmonization index (corresponding to a simultaneous adoption of 4 laws), an estimate of -0.2 explains 30 percent of the actual change in synchronization over our sample period, conditional on all the fixed effects. The estimates in Table 4 advance crucially on the causality front. So far most of the literature on international financial integration has relied either on quantity-based measures, such as international holdings (e.g. Imbs (2006)) or price-based measures, such as the correlation of equity returns (e.g. Bekaert and Harvey (1995)). In contrast to these outcome measures, the legislative-regulatory harmonization index $(H A R M O N)$ reflects structural features of the regulatory and supervisory system that governs financial intermediation; as such, reverse causation is quite unlikely to drive the significant negative correlation shown in Table 4. Moreover, since legislative transposition policies in converting the EU Directives into the national legal order are unilateral (at the country level), while the harmonization index is bilateral reflecting the situation when two countries have adopted the exact same piece of financial legislation, these specifications are unlikely to be driven by other forms of endogeneity.

In Appendix Table 3 we examine the robustness of the negative effect of legislative/regulatory harmonization policies in financial services on output synchronization. The literature on the determinants of world market integration (e.g. Kose et al. (2008); Bekaert, Harvey, Lundblad and Siegel (2011)) has explored the effect of various institutional and financial development indicators (such as creditor's rights, property rights institutions, private credit, etc.). Since most of the usual proxies of institutional efficiency exhibit little within country variability, they will be captured by the country-pair fixed-effects. Appendix Table 3, columns (1)-(2) show that it is the bilateral adoption of the various legislative acts of the FSAP that correlate with output synchronization rather than the unilateral (country-specific) transposition of Directives into national law. In columns (3)-(6) we control for two usually employed measures of financial development, stock market turnover and stock market capitalization. The negative effect of the structural index of financial integration retains its economic and statistical significance.

\section{Instrumental Variables Estimation}

Having established a significant relationship between the structural measure of financial integration and output synchronization (in Table 4) and a similarly negative association between the de-facto 
quantity-based measure of banking integration and output synchronization (in Tables 2 and 3), the next step is to combine the two results in an instrumental variables setting.

\subsection{Identification}

We posit the following first-stage relationship between legislative-regulatory harmonization policies in financial services (HARMON) and cross-border banking integration (BANKINT):

$$
B A N K I N T_{i, j, t}=\delta_{i, j}+\delta_{t}+\gamma H A R M O N_{i, j, t}+X_{i, j, t}^{\prime} \Phi+\nu_{i, j, t}
$$

The index of legislative harmonization policies in financial services $(H A R M O N)$ will serve as a valid "excludable" instrument if: a) It is significantly correlated with banking integration, i.e. there is a strong first-stage relationship. b) Conditional on other factors, legislative/regulatory harmonization policies in financial services affect business cycle synchronization through crossborder financial integration (i.e. $\operatorname{COV}\left(H A R M O N_{i, j, t}, \varepsilon_{i, j, t} \mid X_{i, j, t}^{\prime}, \alpha_{i}, \delta_{t}\right)=0$ where $\varepsilon_{i, j, t}$ is the error term in the second stage (equation 3)).

Our identification scheme links policy changes in a particular aspect of law (financial intermediation) with outcomes in exactly the same industry. Thus the key exclusion restriction for instrument validity seems plausible, because legislative harmonization policy reforms in financial services should affect the patterns of business cycle co-movement primarily by altering cross-border financial activities (see Angrist and Pischke (2008)). The FSAP was designed to spur cross-border financial linkages and develop a single market for financial services in Europe. Thus conditional on other bilateral characteristics, it seems reasonable that harmonization policies in financial services affect output synchronization through increasing bilateral financial linkages.

Conceptually our identification builds on insights of the law and finance literature. This body of work shows that differences in the legal protection of shareholders and creditors have first-order effects on the development of deep and efficient financial markets and intermediaries (see La Porta, Lopez-de-Silanes, Shleifer, and Vishny $(1997,1998)$ ). Of most relevance is the study of La Porta, Lopez-de-Silanes, and Shleifer (2008), who compile a detailed cross-country dataset of securities laws across countries and then examine the impact of such regulations on capital markets. Our identification set-up is, however, more restrictive and thus stronger since we link country-pair reforms in legal practices that aim to make the functioning of the financial system more alike with bilateral changes in financial patterns. 
The country-pair dimension of the harmonization index further alleviates concerns of endogeneity, emerging either from reverse causation or because the instrument is correlated with omitted variables. While the timing of the transposition of the EU Directives into the domestic law may be related to hard-to-account-for unilateral (domestic) conditions, the outcomes we study - financial integration in the first-stage and output synchronization in the second-stage - are bilateral (and time-varying). ${ }^{23}$ Thus to challenge the exogeneity assumption one would require that countries coordinate on the exact timing of the transposition of each piece of legislation, something that does not seem to be the case.

Someone might be worried from anticipation of these regulatory reforms. Yet in practice anticipation effects are not particularly important in our context. First, even if investors have some idea on the timing of the legal adoption of each EU Directive in their country, it seems unlikely that they can also foresee the exact timing of the transposition in another country. Second, since most Directives reduce the cost of cross-border financial intermediation after their adoption, it makes sense for banks to wait for the transposition of the EU laws. Take for example the Settlements Directive that introduced central party clearing, legal enforceability of netting and collateral security. Transaction costs and counter-party risk fell only when both countries transpose the EU Directive into the domestic legal order. Third, if foreign banks increase their lending and borrowing in anticipation of the legal adoption of the EU Directives, then we should not detect a significant first-stage relationship, something we do (see below).

\subsection{First-Stage: Legislative-Regulatory Harmonization in Financial Services and Banking Integration}

In Panel $B$ of Table 5 we examine whether the transposition of EU laws on financial intermediation are relevant for cross-border banking activities. We continue to include country-pair fixed-effects and year fixed-effects, so the coefficient on the harmonization index measures how much financial integration increased/decreased after countries adopt into the local legal order the exact same pieces of financial laws. The coefficient on $H A R M O N$ in column (1) is positive (0.40) and significant at the $99 \%$ confidence level. This suggests that countries that quickly incorporated into domestic law the EU-wide regulatory-legislative harmonization policies in capital markets, insurance, and banking became more financially integrated through international banking activities. ${ }^{24}$

\footnotetext{
${ }^{23}$ We investigated whether the legal adoption of the FSAP Directives correlates with country-level GDP growth, finding insignificant estimates.

${ }^{24}$ Using country-level panel regressions Christensen, Hail, and Leuz (2010) similarly find that following the transposition of the Directives on market abuse and the Directive on transparency market liquidity increases significantly.
} 
Figure 3 illustrates this using as an example the evolution of banking activities and legislative/regulatory harmonization in financial services between Spain and the Netherlands. Banking activities between Spain and the Netherlands increase significantly after 1999 when alongside euro membership both countries adopt at the same time the first Directive of the FSAP on Cross-border Settlements. Banking activities between Spain and the Netherlands further increase in 2002, when both countries adopt at the same time the EU Directives that harmonized insurance services and electronic payments (see Appendix Tables $A$ and $B$ ).

In column (2) we add in the specification a time-varying bilateral index capturing the flexibility of the exchange rate regime. This index enters with a negative and significant estimate suggesting that banking activities have increased significantly among pairs of countries that have adopted more rigid currency regimes. ${ }^{25}$ The first-stage coefficient on the harmonization index falls somewhat (0.33), but retains significance at the $99 \%$ level. In columns (3) and (4) we augment the specification with the gravity controls (i.e. the log of the product of the two countries' GDP and the log of the product of the two countries' population). We also control for differences in per capita GDP. While all three additional control variables enter with significant estimates (coefficients not reported), this has little effect on the impact of legislative/regulatory harmonization in financial services on cross-border banking integration. The positive and highly significant coefficient on $H A R M O N$ across all perturbations suggests that a considerable portion of the recent increase in cross-border banking activities among EU member countries was driven by the harmonization policies in financial services. ${ }^{26}$ In columns (5)-(8) we focus on the post 1995 period. While we lose efficiency, focusing in the period just before and after the introduction of the FSAP is useful to examine the robustness of our results. In all permutations the coefficient on the legislative/regulatory harmonization index is positive and highly significant.

The first stage estimates are in line with the literature in law and economics that argues that prior to FSAP financial market integration in the EU was still unachievable given the diversity of the legal regimes and the costs associated with this diversity (see Enriques and Gatti (2008) and Malcom et al. (2009)). While many argue that the FSAP could have included bolder harmonization measures, the elasticities in Panel $B$ of Table 5 suggest a considerable economic effect; a one standard

\footnotetext{
${ }^{25}$ This finding fits with the evidence from the fear of floating literature (e.g. Calvo and Reinhart (2002); Gelos and Wei (2005)). This research argues that to attract foreign capital, emerging economies are unwilling to let their currencies float; and even when monetary authorities in developing countries argue that they do not manage the currency in practice they do so (Reinhart and Rogoff (2004)). While this body of work focuses on developing economies, our evidence shows a similar pattern across developed countries.

${ }^{26}$ We also examined whether it is the joint adoption of EU Directives that fosters cross-border banking activities or the unilateral transposition by member countries. The estimates clearly show that it is legislative/regulatory harmonization that spurs cross-border banking activities.
} 
deviation increase in the harmonization index, almost doubles banking integration. Kalemli-Ozcan, Papaioannou, and Peydro (2010) show that the strong effect of legislative/regulatory harmonization policies in financial services in spurring cross-border activities is robust to a variety of permutations. Most importantly for our focus here, the first-stage fit is strong. Across all specifications in the full sample the first-stage $F$-score of the excluded instrument (the legislative/regulatory harmonization index) is larger than 10, the rule-of-thumb value that alerts for weak instrument problems (Staiger and Stock (1997); Stock, Wright, and Yogo (2001)). Even when we focus on the post 1995 period, the estimate of $H A R M O N$ is 3 standard errors larger than zero, suggesting a reasonable first-stage fit. ${ }^{27}$

\subsection{SLS Estimates}

We now turn to the second-stage estimates (reported in Panel $A$ of Table 5) that under instrument validity identify the one-way effect of financial integration on output synchronization. ${ }^{28}$ The 2 SLS coefficient of banking integration in column (1) is negative and highly significant. This suggests that on average within country-pair increases in bilateral banking activities driven by legislativeregulatory harmonization policies in financial services lead to more divergent output patterns.

The second stage estimate on $B A N K I N T$ retains significance when we control for the flexibility of the exchange rate regime (in (2) and (4)). ${ }^{29}$ The 2 SLS coefficient on banking integration retains significance when we control for the log of the product of the two countries GDP, the log of the product of the two countries' population, and differences in log per capita GDP in columns (3)(4). The results are similar when we focus in the period $1995-2006$. The estimate in columns (4) and (8) thus imply that conditional on country-pair fixed-factors, common global effects, the flexibility of the exchange rate regime, gravity factors, and output convergence, the component of banking integration explained by harmonization policies in financial services is associated with a lower degree of output synchronization.

The 2SLS coefficients on banking integration are somewhat larger in absolute value than the LS estimates (in Panel $B$ of Table 2). For example, the analogous LS estimate on banking integration to the 2SLS coefficient in column (1) of Table 5 is -0.385 . The larger in absolute magnitude

\footnotetext{
${ }^{27}$ In our set-up the Stock and Yogo (2002) critical value for weak identification is 16.4. 8.96, and 6.66 for critical values of $10 \%, 15 \%$, and $20 \%$ respectively.

${ }^{28}$ The causal effect of banking integration on output synchronization is simply the ratio of the "reduced-form" coefficient of legislative-regulatory harmonization policies on output co-movement (reported in Table 4) to the "firststage" coefficient of $H A R M O N$ on banking integration (reported in Table 5-Panel B).

${ }^{29}$ The same applies when instead of using the bilateral time-varying measure of the flexibility of the exchange rate regime, we control for EU and euro area membership.
} 
of 2SLS estimates suggest that the OLS estimates were contaminated by measurement error and that reverse causation was in practice not a fundamental problem. Specifically there are two main sources of attenuation in the OLS estimates that the 2SLS helps to resolve. First, bilateral banking activities are just one part of financial integration; although international banking activities are by far largest component of foreign investment, theoretical works suggest that the impact of other forms of financial integration, mostly equity investment and FDI, should have a larger impact on cross-border risk sharing and output co-movement than integration that takes the form of debt and direct lending (see Morgan, Rime, and Strahan (2004)). As the harmonization index that we use as an "instrument" for banking integration is much broader than banking, covering legislative convergence in all segments of financial intermediation (specifically in capital markets, insurance industry, company law) the larger second stage coefficients is not surprising. Second, attenuated OLS estimates may arise because a sizable portion of international investment and lending is redirected through financial centers (e.g. Kubelec and Sa (2009); Lane and Milesi-Ferretti (2007)) and thus standard measures of bilateral integration miss indirect linkages. Since our legislativeregulatory harmonization index is truly bilateral and not systematically biased for financial center countries (like Switzerland or the United Kingdom) it accounts for indirect transactions through financial centers. ${ }^{30}$

Our analysis focuses in a sample of advanced economies under a period of unprecedented financial stability. This is key for identification, as theory makes opposing predictions on the partial effect of financial integration on output synchronization depending on the nature of the underlying shocks (as we have discussed in section 2). When countries are hit by productivity shocks that affect the value of the firm's collateral then banking/financial integration tends to amplify these shocks leading to divergent output cycles. In contrast integration facilitates contagion when financial shocks dominate. During our sample period some financial shocks have hit advanced economies. For example the Scandinavian countries witnessed a significant banking crisis in the early $1990 s$. Likewise the Japanese banking system had been under stress in the mid/late $1990 \mathrm{~s}$.

In Table 6 we report LS and instrumental variable panel estimates excluding from the analysis observations when one of the two (or both) countries have experienced a financial/banking crisis, to fully isolate periods that productivity shocks dominate from financial turmoil episodes. In columns

\footnotetext{
${ }^{30}$ Of course the larger in absolute magnitude 2 SLS coefficient may arise because the harmonization index that we use as an instrument is correlated with relevant time-varying country-pair variables. This, however, seems unlikely, since most of the correlates of output synchronization and bilateral international capital holdings are either timeinvariant (e.g. distance, trust, cultural ties) or slow moving (e.g. specialization, trade). Thus they will be captured by the country-pair fixed-effects.
} 
(1)-(3) we use the Reinhart and Rogoff $(2008,2009)$ chronology of major (systemic) financial crises and exclude Spain during the period 1979 - 1985, Japan over the period 1997 - 2001, and Finland and Sweden over the period 1991 - 1994. In columns (4)-(6) we also exclude observations when a minor (non-systemic) financial crisis takes place (when a small number of banks faces solvency problems), again using the Reinhart and Rogoff $(2008,2009)$ classification. $^{31}$ In line with our previous results, the LS specifications in Panel $A$ show that within country-pair increases in banking integration in tranquil times are followed by more divergent output cycles. We obtain the same pattern when we regress output synchronization on the structural measure of financial integration that captures legislative/regulatory harmonization in financial services (in Panel $B$ ); as a result of financial regulatory convergence, output cycles become less synchronized. Finally the second-stage estimates in Panel $C$ show that during tranquil times, increases in cross-border banking activities driven by legislative/regulatory harmonization policies in financial intermediation are followed by divergent output cycles.

\section{A Primer on The Economic Mechanism}

Our results of a significant negative association between cross-border banking integration and output synchronization, while in contrast to previous empirical works, is supportive of the key theoretical predictions of the workhorse international real business cycle model of Backus, Kydland, and Kehoe (1992) and the multi-economy version of the Holmstrom and Tirole (1997) banking model of Morgan, Rime, and Strahan (2004). These models imply that banking integration magnifies productivity shocks (to regions or to countries), making output growth among integrated economies to diverge. In Table 3 we condition on differences in per capita GDP so as to account for the possibility that the negative partial effect of financial integration on output synchronization operates via output convergence. In Table 3 we also reported specifications conditioning on differences in goods trade, to control for the possibility that financial integration leads to divergent output patterns via enlarging trade imbalances. ${ }^{32}$

If banking integration leads to divergent output cycles in tranquil times because it magnifies productivity differences, then we should also observe capital flowing in (out) to the country hit by

\footnotetext{
${ }^{31}$ According to this classification the following countries (year) have experienced a minor (non-systemic) banking crisis. Australia (1989 - 1992), Canada (1983 - 1985), France (1994), Germany (1977 - 1979), Italy (1990 - 1995), the United Kingdom $(1984,1991,1995)$, and the United States $(1989-1991)$. The results are similar if we use the Laeven and Valencia (2010) classification of banking crises.

${ }^{32}$ We thank an anonymous referee for pointing out these two alternative theoretical mechanisms to our attention.
} 
a positive (negative) productivity shock. Since the BIS database records separately foreign bank assets and foreign bank liabilities, we explore this theoretical prediction. Specifically in Table $7 a$ and Table $7 b$ we utilize the information of the BIS on the direction of bank investment (foreign assets of country $i$ banks to country $j$; foreign liabilities of banks in country $j$ to country $i$; foreign assets of country $j$ banks to country $i$; foreign liabilities of banks in country $i$ to country $j$ ) to shed light on the mechanism.

Table $7 a$ reports panel fixed-effect estimates associating the difference in real GDP p.c. growth between country $i$ and country $j$ with three different measures reflecting changes in the external position within each pair of countries. The dependent variable in all specifications is the difference in GDP growth between country $i$ and $j$ in year $t$. In contrast to our estimates in the main Tables we do not take the absolute value, to sign the direction of foreign bank lending and investment; hence a positive (negative) number implies that country $i(j)$ is growing faster than country $j(i)$. In columns (1)-(3) we regress the output growth difference on the change in (the log of the) stock of net foreign external assets held by banks of country $i$ in country $j$ minus foreign liabilities of country $i$ to country $j$. In columns (4)-(6) we decompose changes in net foreign assets and associate GDP growth differences with the change in foreign bank assets of country $i$ in country $j$ and the change of foreign bank assets of country $j$ in country $i$.

As these specifications do not identify causal effects, we also run regressions switching the dependent and the independent variables. In Table $7 b$ GDP growth differences between country $i$ and country $j$ is the explanatory variable, while the three measures on the change in foreign bank asset positions serve as the dependent variables.

The significantly negative coefficient in columns (1)-(3) in both panels suggests that when country $i$ experiences higher productivity growth than country $j$ (or when country $j$ experiences a relative negative shock) then the foreign assets held by banks of country $i$ in country $j$ fall as capital flows into country $i$. The specifications reported in columns (4)-(6) of Table $7 a$ and in columns (4)-(9) of Table $7 b$ show that a positive growth differential between country $i$ and country $j$ is associated with both a reduction of local banks exposure in country $j$ and an increase in lending from banks in country $j$. Thus, while the contemporaneous correlations in Table 7 do not identify causal relationships, they are in line with both international macro/finance theories and banking models predicting by allowing the quick movement of capital across countries, financial -banking in our application- integration makes output cycles to diverge. 


\section{Conclusion}

Identifying the effect of financial integration on the synchronization of economic activity has been difficult given ambiguous theoretical predictions and numerous empirical challenges. Theory predicts a positive association between financial integration and synchronization of economic activity if shocks to financial sector are dominant and/or if there is financial contagion. Theory predicts a negative relationship between integration and synchronization if shocks to real sector dominate in the form of shocks to firms' productivity and/or collateral. Identification has been elusive since common shocks and hard-to-account factors related to sociopolitical proximity between countrypairs simultaneously determine financial integration and synchronization among country-pairs.

To account for the simultaneity bias and reverse causality, we utilize a unique supervisory dataset to construct time-varying de-facto and de-jure financial integration measures for developed country-pairs over last three decades. Our country-pair-time data-set enables us to use a methodology that identifies the effect of financial integration on business cycle synchronization through within country-pair over time changes as opposed to cross-sectional differences as typically done in the literature.

Our results point to the dominance of real productivity/collateral shocks to non-financial firms over shocks to the financial sector in a sample of developed countries in the last three decades. This is plausible given the fact that a 2007-2009 style global financial meltdown did not happen during our sample period. The major banking crisis that affected our countries was the Scandinavian crisis of 1990s, but clearly given its relatively local nature and absence of contagion this crisis was not enough to change the negative effect of financial integration on synchronization to positive.

One caveat of our work is the fact that we focus only on bank integration. Although our dejure measure of integration we have used that is based on law changes that harmonized financial intermediation across the EU markets supposed to capture other forms of integration, we might still miss some alternative mechanisms such as institutional investors who may also respond to the changes in financial laws. Nevertheless, our findings require that we significantly reconsider the conventional wisdom. Contrary to the previous studies and conventional wisdom, we show that increased financial integration leads to divergent economic activity among country-pairs. The policy implications of our study are such that in the absence of a major worldwide banking crisis and associated contagion, developed country financial markets work as expected channeling the funds efficiently. The results can alter drastically in the event of a major shock to the financial system of a country such as the U.S. 


\section{Data Appendix}

Synchronization Index 1 [SYNCH1]: The measure is defined as minus one times the divergence of (logarithmic) real GDP growth between each pair of countries in each year. $S Y N C H 1_{i, j, t} \equiv$ $-\left[\left(\ln Y_{i, t}-\ln Y_{i, t-1}\right)-\left(\ln Y_{j, t}-\ln Y_{j, t-1}\right)\right]$. For output $(Y)$ we use World Bank's real per capita GDP at constant prices series. This index follows Giannone, Lenza and Reichlin (2008). Source: World Bank's World Development Indicators Database (2011).

Synchronization Index 2 [SYNCH2]: The measure follows Morgan, Rime, and Strahan (2004) and is constructed in two steps. First, we regress (logarithmic) real GDP growth separately for each country on country fixed-effects and year fixed-effects, i.e. $\ln Y_{i, t}-\ln Y_{i, t-1}=\gamma_{i}+\phi_{t}+v_{i, t} \forall$ $i, j$. Second, we construct the business cycle synchronization index as the negative of the divergence of the residuals for each country-pair, i.e. $S Y N C H 2_{i, j, t} \equiv-\left|\nu_{i, t}-\nu_{j, t}\right|$. Source: World Bank's World Development Indicators Database (2011).

Synchronization Index 3 [SYNCH3]: The measure is the correlation of the cyclical component of (logarithmic) real GDP as measured with Baxter and King (1999) Band-Pass filter (2,8).Source: World Bank's World Development Indicators Database (2010).

Banking Integration 1 [BANKINT1]: The banking integration index is based on bilateral cross-border holdings (stocks) of banks. Data on bank's cross-border bilateral stocks of assets and liabilities come from the confidential version of BIS's Locational Banking Statistics. The BIS defines banking institutions broadly so "reporting institutions should include not only commercial banks but also savings banks, savings and loan associations, credit unions or cooperative credit banks, building societies, and post office giro institutions, other government-controlled savings banks and other financial institutions if they take deposits or issue close substitutes for deposits" (BIS 2003a,b). For each country-pair and year there are up to four observations. $i$ ) asset holdings (stocks) of banks located in country $i$ in all sectors of the economy in country $j$; ii) asset holdings (stocks) of banks located in country $j$ in all sectors of the economy in country $i$; iii) liabilities (stocks) of banks located in country $i$ to country $j$. iv) liabilities (stocks) of banks located in country $j$ to country $i$. The data is originally expressed in current U.S. dollars. First, we deflate the four series with the U.S. deflator. Second, we standardize the series by dividing asset and liabilities with the sum of the two countries population in each year (using data from World Bank's World Development Indicators Database). Third, we take the average of the log value of real bilateral assets and liabilities in each year. Source: Bank of International Settlements, Locational Banking Statistics (2008). 
Banking Integration 2 [BANKINT2]: The banking integration index is based on bilateral cross-border holdings (stocks) of banks. Data on bank's cross-border bilateral stocks of assets and liabilities come from the confidential version of BIS's Locational Banking Statistics. The BIS defines banking institutions broadly so "reporting institutions should include not only commercial banks but also savings banks, savings and loan associations, credit unions or cooperative credit banks, building societies, and post office giro institutions, other government-controlled savings banks and other financial institutions if they take deposits or issue close substitutes for deposits" (BIS 2003). For each country-pair and year there are up to four observations. $i$ ) asset holdings (stocks) of banks located in country $i$ in all sectors of the economy in country $j$; $i i$ ) asset holdings (stocks) of banks located in country $j$ in all sectors of the economy in country $i$; iii) liabilities (stocks) of banks located in country $i$ to country $j$. iv) liabilities (stocks) of banks located in country $j$ to country $i$. The data is originally expressed in current U.S. dollars. First, we deflate the four series with the U.S. deflator. Second, we standardize the series by dividing asset and liabilities with the sum of the two countries GDP in each year (using data from World Bank's World Development Indicators Database). Third, we take the average of the log value of real bilateral assets and liabilities in each year. Source: Bank of International Settlements, Locational Banking Statistics (2008).

Trade Integration [TRADE]: Index of bilateral trade intensity. The measure is the log of bilateral real (deflated with the U.S. price deflator) exports and imports as a share of two countries's GDP. Source: IMF's Direction of Trade Database (2008).

Specialization $[S P E C]$ : Index of industrial specialization, based on dissimilarities in production. The measure is the sum of the absolute differences in the share of industrial production for nine manufacturing sectors as a share of the total manufacturing production in each pair of countries in each year, i.e. $S P E C_{i, j, t} \equiv \sum_{n=1}^{N}\left|s_{i, t}^{n}-s_{j, t}^{n}\right|$.Source: United Nations Industrial Statistics Database (2008).

Legislative Harmonization in Financial Services [HARMON]: Index of regulatorylegislative harmonization in financial services based on the transposition of the EU Directives of the EU Financial Services Action Plan (FSAP). We construct the bilateral harmonization index in two steps. First, we define 27 indicator variables $\left(L E X_{i, j, t}^{k}\right.$, one for each Directive $k$ ) that equal one if at any given year both countries in each country-pair cell have transposed the Directive into national law and zero otherwise. Second, we create the country-time varying legislative harmonization measure ranging by summing the values of these 27 indicator variables $\left(L E X_{i, j, t}^{k}\right)$. Since the variable is highly skewed in the regressions we use the log value, and add one, i.e., $H A R M O N_{i, j, t} \equiv$ 
$\ln \left(\sum_{k=1}^{K=27}\left(1+L E X_{i, j, t}^{k}\right)\right)$. Source: Kalemli-Ozcan, Papaioannou, and Peydro (2010), based on data from the EU Commission and each EU15 member country.

Exchange Rate Flexibility $[E R C]$ : Bilateral index of the flexibility of the exchange rate. The country-specific index ranges from 1 to 5 where lower values suggest a more rigid regime. We construct the bilateral index by taking the sum of the $\log$ classification of countries $i$ and $j$ in the beginning (January) of each year $t\left(E R C=\ln \left(E R_{i, t}\right)+\ln \left(E R_{j, t}\right)\right)$. Source: Ilzetzki, Reinhart, and Rogoff (2008) and Reinhart and Rogoff (2004).

Euro Area Both [EZ2]: Bilateral index of membership in the euro area. The measure is an indicator variable that takes on the value one if both countries are members of the euro-zone in year $t$ and zero otherwise. Source: European Central Bank.

Euro Area One [EZ1]: Bilateral index of membership in the euro area. The measure is an indicator variable that takes on the value one if only one country is member of the euro-zone in year $t$ and zero otherwise. Source: European Central Bank.

European Union Both [EU2]: Bilateral index of membership in the EU. The measure is an indicator variable that takes on the value one if both countries are members of the EU in year $t$ and zero otherwise. Source: EU Commission.

European Union One [EU1]: Bilateral index of membership in the EU. The measure is an indicator variable that takes on the value one if only one country is member of the EU in year $t$ and zero otherwise. Source: EU Commission.

Income $[G D P]$ : Log level of real GDP (in constant U.S. dollars) for country $i$ and country $j$ in year $t$. In the regressions we use the log of the product of the two countries' GDP (in the previous year). Source: World Bank World Development Indicators Database (2011).

Population $[P O P]$ : $\log$ level of population for country $i$ and country $j$ in year $t$. In the regressions we use the log of the product of the two countries' population (in the previous year). Source: World Bank World Development Indicators Database (2011).

Income Difference $[G D P D I F F]$ : Absolute value of the difference of the log level of real per capita GDP (in constant U.S. dollars) between country $i$ and country $j$ (in the previous year). Source: World Bank World Development Indicators Database (2011).

Trade Difference $[T R A D E D I F F]$ : For each country pair there are four observations in a year. Exports from country $i$ to country $j$. Imports of country $i$ from country $j$. Exports of country $j$ to country $i$. Imports of country $j$ from country $i$. After deflating the data with the US 
CPI, we take the sum of the logs of exports of country $i$ to country $j$ and the imports of country $j$ from country $i$ (exports from $i$ to $j$ ) and the sum of the logs of exports of country $j$ to country $i$ and the imports of country $i$ from country $j$ (exports from $j$ to $i$ ). Then we take the absolute value of the difference of the log level of bilateral exports between country $i$ and country $j$ (in the previous year). Source: IMF's Direction of Trade Database (2008). 


\section{References}

Adam, K., Jappelli, T., Menichini, A., Padula, M., and M. Pagano. 2002. "Analyse, Compare and Apply Alternative Indicators and Monitoring Methodologies to Measure the Evolution of Capital Market Integration in the European Union." Centre for Studies in Economics and Finance, Department of Economics and Statistics, University of Salerno.

Allen, F., and D. Gale. 2000. "Financial Contagion.” Journal of Political Economy, 108(1): 1-33.

Angrist, D., and J. Pischke. 2008. Mostly Harmless Economics: An Empiricist's Companion. Princeton University Press.

Aviat, A., and N. Coeurdacier. 2007. "The Geography of Trade in Goods and Asset Holdings." Journal of International Economics, 71(1): 22-51.

Backus, D., Kehoe, P., and F. Kydland. 1992. "International Real Business Cycles." Journal of Political Economy, 100(4): 745-775.

Balas, A., La Porta, R., Lopez-de-Silanes, F., and A. Shleifer. 2009. "The Divergence of Legal Procedures." American Economic Journal: Economic Policy, 1(2): 138-62.

Bank of International Settlements. 2003a. "Guide to International Financial Statistics", BIS Monetary and Economic Department (Basle, Switzerland) Papers No. 14, February.

Bank of International Settlements. 2003b. "Guide to International Banking Statistics", BIS Monetary and Economic Department (Basle, Switzerland) Papers No. 16, April.

Bartram, S., Griffin, J., and D. Ng. 2010. "How Important are Foreign Ownership Linkages for International Stock Returns?" Mimeo.

Baxter, M., and M. Kouparitsas. 2005. "Determinants of Business Cycle Co-movement: A Robust Analysis." Journal of Monetary Economics, 52(1): 113-157.

Baxter, M., and R. G. King. 1999. "Measuring Business Cycles: Approximate Band-pass Filters for Economic Time-Series." Review of Economics and Statistics, 81(4): 575-593.

Bekaert, G., and C. Harvey. 1995. "Time-varying World Integration." Journal of Finance, 50(2): 403-444.

Bekaert, G., Harvey, C., and C. Lundblad. 2005. "Does Financial Liberalization Spur Economic Growth?" Journal of Financial Economics, 77(1): 3-55.

Bekaert, G., Harvey, C., and C. Lundblad. 2006. "Growth Volatility and Financial Liberalization." Journal of International Money and Finance, 25(3): 370-403.

Bekaert, G., Harvey, C., and C. Lundblad. 2011. "Financial Openness and Productivity." World Development, 39(1): 1-19. 
Bekaert, G., Harvey, C., Lundblad, C., and S. Siegel. 2007. "Global Growth Opportunities and Market Integration." Journal of Finance, 62(3): 1081-1137.

Bekaert, G., Harvey, C., and A. Ng. 2005. "Market Integration and Contagion," Journal of Business, 78: 1-31.

Bekaert, G. and C. Harvey. 2000. "Foreign Speculators and Emerging Equity Markets," Journal of Finance, 55: 565-613.

Bekaert, G., Harvey, C., Lundblad, C., and S. Siegel. 2011. "What Segments Equity Markets," Review of Financial Studies, forthcoming.

Bertrand, M., Duflo, E., and S. Mullainathan. 2004. "How Much Should We Trust Difference in Differences Estimates?" Quarterly Journal of Economics, 119(1): 249-275.

Brunnermeier, M., T. Eisenbach and Y. Sannikov. 2011. "Macroeconomics with Financial Frictions: A Survey." Mimeo.

Calderon, C., Chong, A., and E. Stein. 2007. "Trade Intensity and Business Cycle Synchronization: Are Developing Countries Any Different?" Journal of International Economics, 71(1): $2-21$.

Calvo, G., and E. Mendoza. 2000. "Rational Contagion and the Globalization in Securities Markets." Journal of International Economics, 51(1): 79-119.

Calvo, G., C. Reinhart. 2002. "Fear of Floating." The Quarterly Journal of Economics, 117(2): 379-408.

Calvo, G. 1998. "Capital Market Contagion and Recession: An Explanation of the Russian Virus." Mimeo.

Cameron, A., Gelbach, J., and D. Miller. 2011. "Robust Inference with Multi-way Clustering." Journal of Business and Economic Statistics, 28(2): 238-249.

Canova, F. 1998. "Detrending and Business Cycles Facts." Journal of Monetary Economics, 41(3): $475-512$.

Canova, F. 1999. "Does Detrending Matter For the Determination of the Reference Cycle and the Selection of Turning Points?" Economic Journal, 109(452): 126-150.

Cecchetti, S. G., Flores-Lagunes, A., and S. Krause. 2006. "Assessing the Sources of Changes in the Volatility of Real Growth." NBER Working Paper 11946.

Cetorelli, N., and L. Goldberg. 2011. "Banking Globalization and Monetary Transmission," Journal of Finance, forthcoming.

Christensen, H., and L. Hail, and C. Christian. 2010. "Capital-Market Effects of Securities Regulation: The Role of Implementation and Enforcement." http://ssrn.com/abstract=1745105.

Cornett, M., McNutt, J., Tehranian, H., and P. Strahan. 2011, Forthcoming. "Liquidity Risk Management and Credit Supply in the Financial Crisis." Journal of Financial Economics. 
Devereux, M., and J. Yetman. 2009. "Leverage Constraints and the International Transmission of Shocks." UBC Working Paper.

Doyle, B., and J. Faust. 2005. "Breaks in the Variability and Co-Movement of G7 Economic Growth." Review of Economics and Statistics, 87(4): 721-740.

Ekinci M., Kalemli-Ozcan S., and B. Sørensen. 2008. "Financial Integration within EU Countries: The Role of Institutions, Confidence, and Trust." International Seminar on Macroeconomics.

Enders, Z., Kollman, R., and M. Mueller. 2010. "Global Banking and International Business Cycles." CEPR Discussion Paper 7972.

Enriques, L., and M. Gatti 2008. "Is There a Uniform EU Securities Law After the Financial Services Action Plan?" Stanford Journal of Law, Business, and Finance, 14(1).

Enriques, L., and P. Volpin 2007. "Corporate Governance Reforms in Continental Europe." Journal of Economic Perspectives, 21(1): 117-140.

Forbes K. and R. Rigobon. 2002. "No Contagion, Only Interdependence: Measuring Stock Market Comovements." Journal of Finance, LVII: 2223-2261.

Frankel, J., and A. Rose. 1998. "The Endogeneity of the Optimum Currency Area Criterion." Economic Journal, 108(6): 1009-1025.

Frankel, J., and S. Schmukler. 1998. "Crises, Contagion, and Country Funds: Effects on East Asia and Latin America." In Management of Capital Flows and Exchange Rates: Lessons from the Pacific Rim ed. Glick, R., Cambridge University Press.

Freixas, X., and P. M. Bruno, and J. Rochet. 2000. "Systemic Risk, Interbank Relations, and Liquidity Provision by the Central Bank," Journal of Money, Credit and Banking, 32(3): 611-38.

Garcia-Herrero, A., and J. M. Ruiz. 2008. "Do Trade and Financial Links Foster Business Cycle Synchronization in a Small Open Economy." Moneda y Credito, 226(1): 187-226.

Gelos, G., and S.-J. Wei. 2005. "Transparency and International Portfolio Holdings." Journal of Finance, 60(6): 2987-3020.

Giannetti, M., and Y. Yafeh. 2008. "Do Cultural Differences Between Contracting Parties Matter? Evidence from Syndicated Bank Loans." ECGI Finance Working Paper No. 224/2008.

Giannone, D., Lenza M., and L. Reichlin. 2008. "Business Cycles in the Euro Area." in Europe and the Euro, eds: Alesina, A. and F. Giavazzi: 141-167.

Guiso L., Sapienza P., and L. Zingales. 2009. "Cultural Biases in Economic Exchange?" Quarterly Journal of Economics, 124(3).

Heathcote J. and F. Perri. 2004. "Financial Globalization and Real Regionalization." Journal of Economic Theory, 119(1): 207-43.

Henry, P. B. 2000. "Stock Market Liberalization, Economic Reform, and Emerging Market Equity Prices." Journal of Finance, 55(2): 529-564. 
Holmstrom, B., and J. Tirole. 1997. "Financial Intermediation, Loanable Funds, and the Real Sector." Quarterly Journal of Economics, 112(3): 663-691.

Ilzetzki E., Reinhart, C., and K. Rogoff. 2008. "Exchange Rate Arrangements Entering the 21st Century: Which Anchor Will Hold." University of Maryland Working Paper.

Iyer, R., and J.-L. Peydro. 2011. "Interbank Contagion at Work: Evidence from a Natural Experiment." Review of Financial Studies, 24: 1337-77.

Imbs, J. 2004. "Trade, Specialization and Synchronization." Review of Economics and Statistics, 86(3): 723-734.

Imbs, J. 2006. "The Real Effects of Financial Integration." Journal of International Economics, 68(2): 296-324.

Inklaar, R., Jong-A-Pin, R., and J. de Haan. 2008. "Trade and Business Cycle Synchronization in OECD Countries - A Re-examination." European Economic Review, 52(2): 646-666.

Ivashina, V., and D. Scharfstein. 2010. "Bank Lending During the Financial Crisis of 2008." Journal of Financial Economics, 97(3): 319-338.

Jayaratne, J., and P. Strahan. 1997. "The Finance-Growth Nexus: Evidence from Bank Branch Deregulation." Quarterly Journal of Economics, 111(3): 639-670.

Jimenez, G., Mian, A., Peydro, J.-L., and J. Saurina. 2011. "Local versus Aggregate Lending Channels: The Effects of Securitization on Corporate Credit Supply in Spain." NBER Working Paper 16595.

Jimenez, G., Ongena, S., Peydro, J.-L., and J. Saurina. 2011. "Credit Supply and Monetary Policy: Identifying the Bank Balance-Sheet Channel with Loan Applications." American Economic Review, Forthcoming.

Jotikasthira, C., Lundblad, C., T. Ramadorai. 2009. "Asset Fire Sales and Purchases and the International Transmission of Financial Shocks." Mimeo.

Kalemli-Ozcan, S., Kamil, H., and C. Villegas-Sanchez. 2010. "What Hinders Investment in the Aftermath of Financial Crises? Insolvent Firms or Illiquid Banks?" NBER Working Paper 16528.

Kalemli-Ozcan, S., Papaioannou, E., and J. Peydro. 2010 "What Lies Beneath the Euro's Effect on Financial Integration? Currency Risk, Legal Harmonization, or Trade." Journal of International Economics, 81(1): 75-88.

Kalemli-Ozcan, S., Sørensen, B. E., and O. Yosha. 2001. "Regional Integration, Industrial Specialization and the Asymmetry of Shocks across Regions." Journal of International Economics, 55(1): 107-137.

Kalemli-Ozcan, S., Sørensen, B. E., and O. Yosha. 2003. "Risk Sharing and Industrial Specialization: Regional and International Evidence." American Economic Review, 93(3): 903-918. 
Kalemli-Ozcan, S., Sørensen, B. E., Reshef, A., and O. Yosha. 2010. "Why Does Capital Flow to Rich States?" Review of Economics and Statistics, 92(4), 769-783.

Kalemli-Ozcan, S., Sorensen, B. E., and V. Volosovych. 2010. "Deep Financial Integration and Macroeconomic Volatility." NBER Working Paper 15900.

Kalemli-Ozcan, S., Manganelli, S., Papaioannou, E. and J.-L. Peydro. 2009. "Financial Integration and Risk Sharing: The Role of Monetary Union" in: Mackowiak, B., Mongelli, F. P., Noblet, G., Smets, F. (Ed.), The Euro at Ten: Lessons and Challenges, 116-155, European Central Bank.

Kalemli-Ozcan, S., Papaioannou, E. and F. Perri. 2012. "Global Banks and Crisis Transmission," Harvard Mimeo.

Kaminsky, G. and C. Reinhart. 2000. "On Crises, Contagion, and Confusion." Journal of International Economics, 51, 15-38.

Kaminsky, G., C. Reinhart and C. Vegh . 2003. "The Unholy Trinity of Financial Contagion." Journal of Economic Perspectives, 17(4):51-74.

Kaminsky, G., R. K. Lyons, and S. Schmukler. 2001. "Mutual Fund Investment in Emerging Markets: An overview." World Bank Economic Review, 15: 315-340.

Kaminsky, G., R. K. Lyons, and S. Schmukler. 2004. "Managers, Investors, and Crises: Investment Strategies of Mutual Funds", Journal of International Economics, 64(1): 113-134.

Khwaja, A., and A. Mian. 2008. "Tracing the Impact of Bank Liquidity Shocks: Evidence from an Emerging Market." American Economic Review, 98(4): 1413-1442.

Kose, A., Prasad, E., Rogoff, K., and S.-J. Wei. 2009. "Financial Globalization: A Reappraisal." IMF Staff Papers, 56(1): 8-62.

Kose, M. A., Otrok C., and E. Prasad. 2008. "Global Business Cycles: Convergence or Decoupling?" IZA Discussion Paper No. 3442.

Kose, A., Prasad, E., M. Terrones. 2003. "How Does Globalization Affect the Synchronization of Business Cycles?," American Economic Review, vol. 93(2), pages 57-62, May.

Kraay, A., and J. Ventura. 2000. "Current Accounts in Debtor and Creditor Countries." Quarterly Journal of Economics, 115(4): 1137-1166.

Kraay, A., and J. Ventura. 2007. "Comparative Advantage and the Cross-Section Of Business Cycles." Journal of the European Economic Association, 5(6): 1300-1333.

Krugman, P. 1991. Geography and Trade. Cambridge, MIT Press.

Kubelec, C., and F. Sa. 2009. "The Geographical Composition of National External Balance Sheets: 1980-2005." Bank of England and University of Cambridge Working Paper.

Laeven, L., and F. Valencia. 2010. "Systemic Banking Crises: A New Database," IMF Working Paper No. 08/224, August 2008, available at: http://www.luclaeven.com/Data.htm. 
La Porta, R., Lopez-de-Silanes, F., and A. Shleifer. 2008. "The Economic Consequences of Legal Origins," Journal of Economic Literature, 46(2): 285-332.

La Porta, R., Lopez-de-Silanes, F., Shleifer, A., and R. Vishny. 1997. "Legal Determinants of External Finance." Journal of Finance, 52(3): 1131-1150.

La Porta, R., Lopez-de-Silanes, F., Shleifer, A., and R. Vishny. 1998. "Law and Finance." Journal of Political Economy, 106(6): 1113-1155.

Lane, P., and G. Milesi-Ferretti. 2007. "The External Wealth of Nations Mark II." Journal of International Economics, 73(1): 223-250.

Lane, P., and G. Milesi-Ferretti. 2008. "International Investment Patterns." Review of Economics and Statistics, 90(3): 518-537.

Lane, P. and G. Milesi-Ferretti. 2011. "The Cross-Country Incidence of the Global Crisis." IMF Economic Review, 59(1): 77-110.

Maddaloni, A., and J.-L. Peydro. Forthcoming. "Bank Risk-Taking, Securitization, Supervision, and Low Interest Rates: Evidence from the Euro Area and U.S. Lending Standards." Review of Financial Studies.

Malcolm, K., Tilden, M., and T. Wilsdon. 2009. "Evaluation of the Economic Impacts of the Financial Services Action Plan." CRA International report prepared for the European Commission, Internal Market and Services DG.

Mendoza, E., and V. Quadrini. 2010. "Financial Globalization, Financial Crises and Contagion." Journal of Monetary Economics, 56: 78-111.

Mian, A. 2006. "Distance Constraints: The Limits of Foreign Lending in Poor Economies." Journal of Finance, 61(6): 1465-1505.

Morgan, D. P., Rime, B., and P. Strahan. 2004. "Bank Integration and State Business Cycles," Quarterly Journal of Economics, 119(3): 1555-85.

Obstfeld, M. 1994. "Risk-Taking, Global Diversification, and Growth." American Economic Review, 84(5): 1310-1329.

Ongena, S., Peydro, J.-L. and N. van Horen. 2012. "Shocks Abroad, Pain at Home? Bank-Firm Level Evidence on Financial Contagion during the 2007-2009 Crisis," UPF Mimeo.

Otto, G., Voss, G., and L. Willard. 2001. "Understanding OECD Output Correlations." Reserve Bank of Australia Research Discussion Paper No 2001/05.

Papaioannou, E. 2009. "What Drives International Bank Flows? Politics, Institutions and Other Determinants." Journal of Development Economics, 88(2): 269-281.

Paravisini, D. 2008. "Local Bank Financial Constraints and Firm Access to External Finance." Journal of Finance, 63(5): 2161-2193. 
Paravisini, D., Rappoport, V., Schnabl, P., and D. Wolfenzon. 2010. "Dissecting the Effect of Credit Supply on Trade: Evidence from Matched Credit-Export Data." Working Paper.

Pavlova, A. and R. Rigobon. 2011. "International Macro-Finance." Mimeo.

Peek, J., and E. Rosengren. 2000. "Collateral Damage: Effects of the Japanese Bank Crisis on Real Activity in the United States," American Economic Review, 90: 30-45.

Perri, F., and V. Quadrini. 2010. "International Recessions." USC Working Paper.

Portes, R. and H. Rey. 2005. "The Determinants of Cross-Border Equity Flows." Journal of International Economics, 65(2): 269-296.

Puri, M., Rocholl, J. and S. Steffen. 2011. "Global Retail Lending in the aftermath of the U.S. Financial Crisis: Distinguishing between Supply and Demand Effects," Journal of Financial Economics, 100: 556-578.

Quinn, W. 2003. "Does Capital Account Liberalization Lead to Economic Growth? An Empirical Investigation" Empirical Economics, 28(4): 753-765.

Reinhart, C. and K. Rogoff. 2004. "The Modern History of Exchange Rate Arrangements: A Reinterpretation." Mimeo.

Reinhart, C. and K. Rogoff. 2009. "This Time Is Different: Eight Centuries of Financial Folly." Princeton, NJ: Princeton University Press.

Reinhart, C. and K. Rogoff. 2008. "Banking Crises: An Equal Opportunity Menace." NBER Working Paper No. 14587.

Rice, T., and P. Strahan. Forthcoming. "Does Credit Competition Affect Small-Firm Finance?" Journal of Finance.

Rochet, J., and J., Tirole. 1996. "Interbank Lending and Systemic Risk," Journal of Money, Credit and Banking, 28(4): 733-62.

Rose, A. 2009. "Understanding Business Cycle Synchronization: Is Inflation Targeting Paving the Way to Asian Monetary Union?" University of California-Berkeley Working Paper.

Rose, A., and M. Spiegel. 2004. "A Gravity Model of Sovereign Lending: Trade, Default, and Credit." NBER Working Paper 9285.

Rose, A. and M. Spiegel. 2010. "The Causes and Consequences of the 2008 Crisis: International Linkages and American Exposure," Pacific Economic Review, forthcoming.

Schnabl, P. 2011. "The International Transmission of Bank Liquidity Shocks: Evidence from an Emerging Market." Journal of Finance, forthcoming.

Staiger, D., and J. Stock. 1997. "Instrumental Variables Regression with Weak Instruments." Econometrica, 65(3): 557-86. 
Stock, J. H., Wright, J. H., M. Yogo. 2002. "A Survey of Weak Instruments and Weak Identification in Generalized Method of Moments." Journal of Business and Economic Statistics, 20(4): 518-529.

Van Rijckeghem, C. and B. Weder. 2003. "Spillovers through Banking Centers: a Panel Data Analysis of Bank Flows," Journal of International Money and Finance, 22(4): 483-509.

Wooldridge, P. D. 2002. "Uses of the BIS Statistics: An Introduction. " BIS (Basle, Switzerland) Quarterly Review, March. 
Table 1: Descriptive Statistics

\begin{tabular}{|c|c|c|c|c|c|c|c|c|}
\hline & Obs. & mean & st. dev. & $\min$ & $p 25$ & p50 & $p 75$ & $\max$ \\
\hline & \multicolumn{8}{|c|}{ Panel A: Summary Statistics } \\
\hline SYNCH1 & 4229 & -1.776 & 1.560 & -11.184 & -2.438 & -1.351 & -0.633 & 0.000 \\
\hline SYNCH2 & 4229 & -1.565 & 1.418 & -12.090 & -2.124 & -1.187 & -0.553 & 0.000 \\
\hline BANKINT1 & 4229 & 588.118 & 1307.821 & 0.000 & 30.872 & 137.277 & 529.778 & 14693.050 \\
\hline BANKINT2 & 4229 & 0.026 & 0.053 & 0.000 & 0.001 & 0.007 & 0.025 & 0.570 \\
\hline HARMON & 4229 & 0.965 & 3.684 & 0.000 & 0.000 & 0.000 & 0.000 & 22.000 \\
\hline
\end{tabular}

Panel B: Accounting for Country-Pair Fixed-Effects (within country-pair time)

$\begin{array}{lcccccccc}\text { SYNCH1 } & 4229 & 0.000 & 1.413 & -8.777 & -0.653 & 0.273 & 0.937 & 3.584 \\ \text { SYNCH2 } & 4229 & 0.000 & 1.343 & -10.212 & -0.536 & 0.309 & 0.880 & 3.253 \\ \text { BANKINT1 } & 4229 & 0.000 & 852.444 & -4979.490 & -134.889 & -8.752 & 40.406 & 12205.790 \\ \text { BANKINT2 } & 4229 & 0.000 & 0.031 & -0.185 & -0.005 & 0.000 & 0.002 & 0.424 \\ \text { HARMON } & 4229 & 0.000 & 3.558 & -2.522 & -1.786 & 0.000 & 0.000 & 20.286\end{array}$

Panel C: Accounting for Year Fixed-Effects (across country-pair cross section)

\begin{tabular}{lcccccccc} 
SYNCH1 & 4229 & 0.000 & 1.500 & -8.197 & -0.650 & 0.335 & 1.027 & 2.973 \\
SYNCH2 & 4229 & 0.000 & 1.323 & -8.945 & -0.570 & 0.255 & 0.861 & 3.117 \\
BANKINT1 & 4229 & 0.000 & 1252.387 & -1650.328 & -476.045 & -216.144 & 0.368 & 13228.810 \\
BANKINT2 & 4229 & 0.000 & 0.051 & -0.062 & -0.022 & -0.012 & 0.000 & 0.515 \\
HARMON & 4229 & 0.000 & 2.689 & -10.176 & 0.000 & 0.000 & 0.000 & 12.477 \\
\hline
\end{tabular}

The table reports summary statistics of the main variables used in the empirical analysis. SYNCH1 is the negative value of the absolute difference in real GDP growth between country $i$ and country $j$ in year $t$. SYNCH2 is the negative of the absolute difference of residual real GDP growth between country $i$ and country $j$ in year $t$. BANKINTII denotes the average of bilateral stocks of assets and liabilities of countries $i$ and $j$ normalized by the sum of the two countries' population in year $t$. In the empirical specifications we use the log of this measure (BANKINT1). BANKINT2 denotes the average of the logs of bilateral stocks of assets and liabilities normalized by the sum of the two countries' GDP (BANKINT2). In the empirical specifications we use the log of this measure (BANKINT2). HARMON is a bilateral index of legislative and harmonization policies in financial services in the context of the Financial Services Action Plan (FSAP), initiated by the EU Commission in 1998 to integrate financial services in Europe. The value for each country-pair ranges from 0 to 27, with higher values suggesting a higher degree of harmonization. For details on the construction of all variables see Section 3 and the Data Appendix.

Panel A gives summary statistics. Panel B reports summary statistics that explore the within country-pair time variation of the data (conditioning on country-pair fixed-effects). Panel C reports summary statistics that explore the across country-pair cross sectional variation of the data (conditioning on year fixed-effects). 
Table 2: Banking Integration and Business Cycle Synchronization Cross-Sectional and Panel (Country-Pair) Fixed-Effects Specifications

\begin{tabular}{|c|c|c|c|c|c|c|c|c|}
\hline & \multicolumn{4}{|c|}{ Annual Data } & \multicolumn{4}{|c|}{ 5-year data } \\
\hline & \multicolumn{2}{|c|}{ BANKINT1 } & \multicolumn{2}{|c|}{ BANKINT2 } & \multicolumn{2}{|c|}{ BANKINT1 } & \multicolumn{2}{|c|}{ BANKINT2 } \\
\hline & SYNCH1 & $\mathrm{SYNCH} 2$ & SYNCH1 & SYNCH2 & SYNCH3 & SYNCH3 & SYNCH3 & SYNCH3 \\
\hline & (1) & (2) & (3) & (4) & $(5)$ & $(6)$ & (7) & $(8)$ \\
\hline \multicolumn{9}{|c|}{ Panel A: Cross-Sectional ("Between") Estimates } \\
\hline $\begin{array}{l}\text { Banking Integration } \\
(\text { BANKINT) }\end{array}$ & $\begin{array}{c}0.1272 \\
(0.029) \\
4.42\end{array}$ & $\begin{array}{c}0.1039 \\
(0.0193) \\
5.38\end{array}$ & $\begin{array}{c}0.1327 \\
(0.0289) \\
4.59\end{array}$ & $\begin{array}{c}0.1111 \\
(0.0193) \\
5.76\end{array}$ & $\begin{array}{c}0.0391 \\
(0.011) \\
3.70\end{array}$ & $\begin{array}{c}0.0451 \\
(0.017) \\
2.68\end{array}$ & $\begin{array}{c}0.0429 \\
(0.011) \\
4.04\end{array}$ & $\begin{array}{c}0.0530 \\
(0.017) \\
3.05\end{array}$ \\
\hline $\begin{array}{l}\text { Trade } \\
(T R A D E)\end{array}$ & & & & & & $\begin{array}{c}4.3568 \\
(2.1797) \\
2.00\end{array}$ & & $\begin{array}{c}3.8234 \\
(2.1858) \\
1.75\end{array}$ \\
\hline $\begin{array}{l}\text { Specialization } \\
(S P E C)\end{array}$ & & & & & & $\begin{array}{c}-0.0123 \\
(0.0270) \\
-0.46\end{array}$ & & $\begin{array}{c}-0.0076 \\
(0.0270) \\
-0.28\end{array}$ \\
\hline R-squared (between) & 0.114 & 0.161 & 0.122 & 0.180 & 0.083 & 0.170 & 0.098 & 0.18 \\
\hline \multicolumn{9}{|c|}{ Panel B: Panel Estimates ("Within") with Country-Pair and Year/Period Fixed-Effects } \\
\hline $\begin{array}{l}\text { Banking Integration } \\
(\text { BANKINT) }\end{array}$ & $\begin{array}{c}-0.3852 \\
(0.0622) \\
-6.19\end{array}$ & $\begin{array}{c}-0.0718 \\
(0.0278) \\
-2.58\end{array}$ & $\begin{array}{c}-0.3947 \\
(0.0639) \\
-6.18\end{array}$ & $\begin{array}{c}-0.0752 \\
(0.0283) \\
-2.65\end{array}$ & $\begin{array}{c}-0.0430 \\
(0.027) \\
-1.62\end{array}$ & $\begin{array}{c}-0.0741 \\
(0.026) \\
-2.81\end{array}$ & $\begin{array}{c}-0.0429 \\
(0.027) \\
-1.59\end{array}$ & $\begin{array}{c}-0.0745 \\
(0.027) \\
-2.76\end{array}$ \\
\hline $\begin{array}{l}\text { Trade } \\
(T R A D E)\end{array}$ & & & & & & $\begin{array}{c}-2.5686 \\
(1.2100) \\
-2.12\end{array}$ & & $\begin{array}{c}-2.5885 \\
(1.2158) \\
-2.13\end{array}$ \\
\hline $\begin{array}{l}\text { Specialization } \\
(S P E C)\end{array}$ & & & & & & $\begin{array}{c}-0.0089 \\
(0.0204) \\
-0.44\end{array}$ & & $\begin{array}{c}-0.0088 \\
(0.0205) \\
-0.43\end{array}$ \\
\hline R-2 (within) & 0.130 & 0.147 & 0.130 & 0.148 & 0.232 & 0.280 & 0.231 & 0.28 \\
\hline Observations & 4,229 & 4,229 & 4,229 & 4,229 & 755 & 480 & 755 & 480 \\
\hline Country-pairs & 153 & 153 & 153 & 153 & 153 & 153 & 153 & 153 \\
\hline
\end{tabular}

\section{Table 2 - Notes}

Panel A reports cross-sectional (between) coefficients. Panel B reports panel fixed-effect (within) coefficients that include a vector of country-pair fixed-effects and a vector of year/period fixed-effects. In the panel models in Panel B standard errors are adjusted for country-pair level heteroskedasticity and autocorrelation. In specifications (1) and (3) the dependent variable is minus one times the absolute difference in real GDP growth between country $i$ and country $j$ in year $t$ (SYNCH1). In specifications (2) and (4) the dependent variable is minus one times the absolute difference of residual real GDP growth between country $i$ and country $j$ in year $t$ (SYNCH2). These models are based on annual observations that cover the period 1978-2006. In columns (5)-(8) the dependent variable is the correlation of the cyclical component of real p.c. GDP between country $i$ and $j$ in each of the 6 five-year periods that cover the period 1978-2006 (SYNCH3; estimated with the Baxter and King Band-Pass filter $(2,8))$.

BANKINT1 denotes the one period lagged value of the average of the logs of bilateral stocks of assets and liabilities normalized by the sum of the two countries' population in year $t$. BANKINT2 denotes the one year lagged value of the average of the logs of bilateral stocks of assets and liabilities normalized by the sum of the two countries' GDP in year t. TRADE denotes the log of sum of real bilateral imports and exports of both countries as a share of the two countries' GDP. SPEC is an index of specialization that reflects the dis-similarities in industrial production (in manufacturing) between the two countries in each period. In columns (5)-(8) we use the values of BANKINT1, BANKINT2, TRADE and SPEC in the end of the previous (five-year) period. The Data Appendix and Section 3 give details on the construction and the sources of all variables. The Table also gives the number of country-pairs, the number of observations, the between R-squared (for the cross-sectional models) and the within Rsquared (for the panel fixed-effect specifications). 
Table 3: Banking Integration and Business Cycle Synchronization. Sensitivity Analysis Panel (Country-Pair) Fixed-Effects Specifications

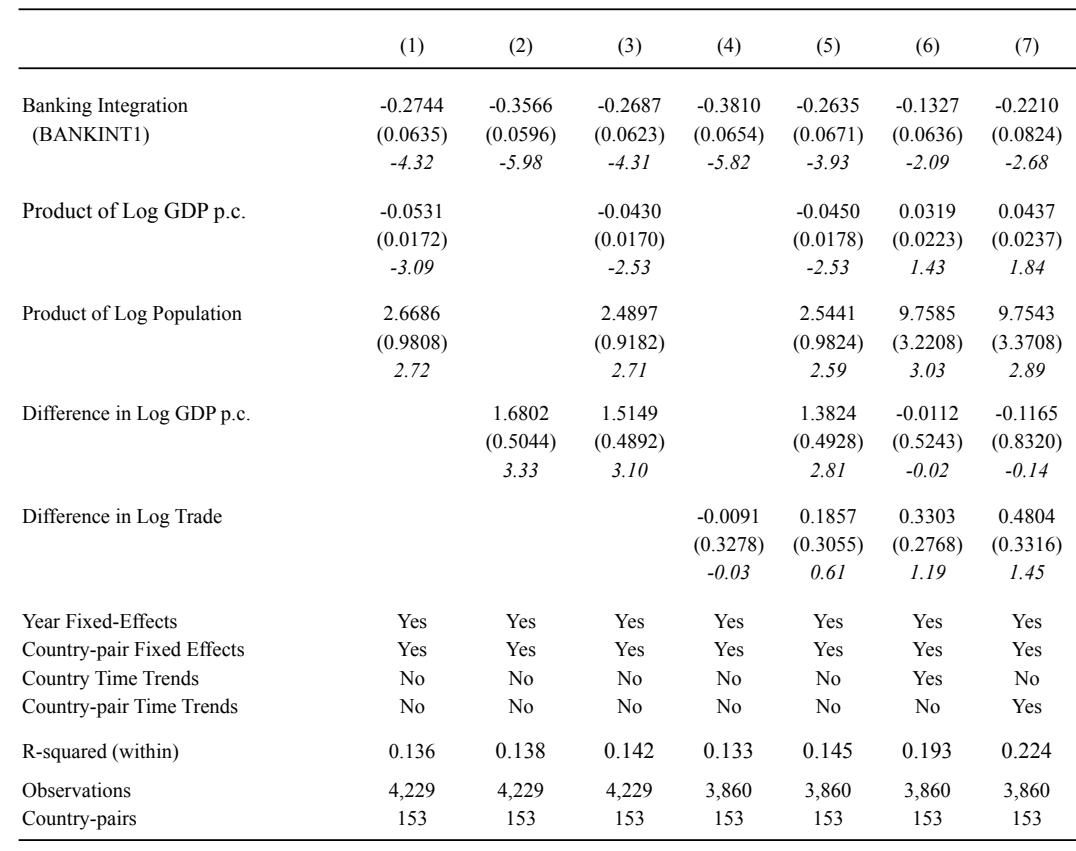

The Table reports panel fixed-effects estimates. Standard errors are adjusted for country-pair level heteroskedasticity and autocorrelation and corresponding t-statistics are reported below the estimates. The dependent variable is minus one times the absolute difference in real GDP growth between country $i$ and country $j$ in year $t$ (SYNCH1). BANKINT1 denotes the one period lagged value of the average of the logs of bilateral stocks of assets and liabilities normalized by the sum of the two countries' population in year t.

The specifications in all columns (1)-(5) and (5)-(7) include as additional controls the log of the product of the two countries' GDP in the previous year and the log of the product of the two countries' population in the previous year. The specifications in columns (2), (3), (5)(7) also include as control the absolute value of the difference in $\log$ per capita GDP between countries $i$ and $j$ in the previous year. The specifications in columns (4)-(7) include as control the absolute value of the difference in $\log$ trade shares between countries $i$ and $j$ in the previous year, where trade share of country $i$ is given by sum of exports and imports as a share of country i's GDP. The specification in column (6) includes a vector of country-specific linear time trends (coefficients not reported). The specification in column (7) includes a vector of country-pair specific linear time trends (coefficients not reported). All specifications include a vector of country-pair fixedeffects and a vector or time (year) fixed-effects (constants not reported).

\begin{tabular}{|c|c|c|c|c|c|c|c|}
\hline & (1) & (2) & (3) & (4) & (5) & (6) & (7) \\
\hline $\begin{array}{l}\text { Banking Integration } \\
\text { (BANKINT2) }\end{array}$ & $\begin{array}{c}-0.2835 \\
(0.0642) \\
-4.41\end{array}$ & $\begin{array}{c}-0.3646 \\
(0.0610) \\
-5.98\end{array}$ & $\begin{array}{c}-0.2749 \\
(0.0624) \\
-4.40\end{array}$ & $\begin{array}{c}-0.3904 \\
(0.0673) \\
-5.80\end{array}$ & $\begin{array}{c}-0.2701 \\
(0.0673) \\
-4.01\end{array}$ & $\begin{array}{c}-0.1329 \\
(0.0640) \\
-2.08\end{array}$ & $\begin{array}{c}-0.2189 \\
(0.0828) \\
-2.64\end{array}$ \\
\hline Product of Log GDP p.c. & $\begin{array}{c}-0.0544 \\
(0.0168) \\
-3.23\end{array}$ & & $\begin{array}{c}-0.0449 \\
(0.0167) \\
-2.69\end{array}$ & & $\begin{array}{c}-0.0468 \\
(0.0175) \\
-2.68\end{array}$ & $\begin{array}{c}0.0300 \\
(0.0221) \\
1.36\end{array}$ & $\begin{array}{c}0.0402 \\
(0.0234) \\
1.72\end{array}$ \\
\hline Product of Log Population & $\begin{array}{c}2.7060 \\
(0.9717) \\
2.78\end{array}$ & & $\begin{array}{c}2.5462 \\
(0.9135) \\
2.79\end{array}$ & & $\begin{array}{c}2.5940 \\
(0.9765) \\
2.66\end{array}$ & $\begin{array}{c}9.8045 \\
(3.2269) \\
3.04\end{array}$ & $\begin{array}{c}9.8351 \\
(3.3813) \\
2.91\end{array}$ \\
\hline Difference in Log GDP p.c. & & $\begin{array}{c}1.6537 \\
(0.5066) \\
3.26\end{array}$ & $\begin{array}{c}1.4805 \\
(0.4863) \\
3.04\end{array}$ & & $\begin{array}{c}1.3500 \\
(0.4893) \\
2.76\end{array}$ & $\begin{array}{c}-0.0272 \\
(0.5231) \\
-0.05\end{array}$ & $\begin{array}{c}-0.1467 \\
(0.8296) \\
-0.18\end{array}$ \\
\hline Difference in Trade & & & & $\begin{array}{c}0.0007 \\
(0.3285) \\
0.00\end{array}$ & $\begin{array}{c}0.1944 \\
(0.3056) \\
0.64\end{array}$ & $\begin{array}{c}0.3334 \\
(0.2771) \\
1.20\end{array}$ & $\begin{array}{c}0.4812 \\
(0.3320) \\
1.45\end{array}$ \\
\hline Year Fixed-Effects & Yes & Yes & Yes & Yes & Yes & Yes & Yes \\
\hline Country-pair Fixed Effects & Yes & Yes & Yes & Yes & Yes & Yes & Yes \\
\hline Country Time Trends & No & No & No & No & No & Yes & No \\
\hline Country-pair Time Trends & No & No & No & No & No & No & Yes \\
\hline R-squared (within) & 0.137 & 0.138 & 0.143 & 0.133 & 0.145 & 0.193 & 0.224 \\
\hline Observations & 4,229 & 4,229 & 4,229 & 3,860 & 3,860 & 3,860 & 3,860 \\
\hline Country-pairs & 153 & 153 & 153 & 153 & 153 & 153 & 153 \\
\hline
\end{tabular}

The Table reports panel fixed-effects estimates. Standard errors are adjusted for country-pair level heteroskedasticity and autocorrelation The Table reports panel fixed-effects estimates. Standard errors are adjusted for country-pair level heteroskedasticity and autocorrelation and corresponding -statistics are reported below the estimates. The dependent varable is mis one times the absolute difference in rea

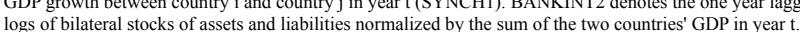

The specifications in all columns (1)-(5) and (5)-(7) include as additional controls the log of the product of the two countries' GDP in the The specifications in all columns (1)-(5) and (5)-(7) include as additional controls the log of the product of the two countries' GDP in the previous year and the log of the product of the two countries' population in the previous year. The specifications in columns (2), (3), (5)-
(7) also include as control the absolute value of the difference in log per capita GDP between countries $i$ and $j$ in the previous year The specifications in columns (4)-(7) include as control the absolute value of the difference in $\log$ trade shares between countries $i$ and $j$ in the specifications in columns (4)-(7) include as control the absolute value of the difference in $\log$ trade shares between countries 1 and $j$ in the
previous year, where trade share of country $i$ is given by sum of exports and imports as a share of country i's GDP. The specification in column (6) includes a vector of country-specific linear time trends (coefficients not reported). The specification in column (7) includes a vector of country-pair specific linear time trends (coefficients not reported). All specifications include a vector of country-pair fixedeffects and a vector or time (year) fixed-effects (constants not reported). 
Table 4: Legislative Harmonization in Financial Services and Business Cycle Synchronization Panel (Country-Pair) Fixed-Effects Specifications

\begin{tabular}{|c|c|c|c|c|c|c|c|c|c|c|c|c|}
\hline & \multicolumn{6}{|c|}{$1978-2006$} & \multicolumn{6}{|c|}{$1995-2006$} \\
\hline & (1) & (2) & (3) & (4) & (5) & (6) & (7) & $(8)$ & (9) & $(10)$ & (11) & (12) \\
\hline \multirow[t]{2}{*}{$\begin{array}{l}\text { Financial Sector Harmonization } \\
(H A R M O N)\end{array}$} & $\begin{array}{l}-0.2420 \\
(0.0430)\end{array}$ & $\begin{array}{l}-0.2262 \\
(0.0432)\end{array}$ & $\begin{array}{l}-0.1652 \\
(0.0689)\end{array}$ & $\begin{array}{l}-0.2662 \\
(0.0849)\end{array}$ & $\begin{array}{l}-0.2452 \\
(0.0912)\end{array}$ & $\begin{array}{l}-0.2343 \\
(0.0838)\end{array}$ & $\begin{array}{l}-0.1518 \\
(0.0796)\end{array}$ & $\begin{array}{l}-0.1776 \\
(0.0762)\end{array}$ & $\begin{array}{l}-0.1466 \\
(0.0589)\end{array}$ & $\begin{array}{l}-0.1254 \\
(0.0630)\end{array}$ & $\begin{array}{l}-0.2776 \\
(0.0911)\end{array}$ & $\begin{array}{l}-0.2924 \\
(0.0981)\end{array}$ \\
\hline & -5.62 & -5.24 & -2.40 & -3.14 & -2.69 & -2.80 & -1.91 & -2.33 & -2.49 & -1.99 & -3.05 & -2.98 \\
\hline R-squared (within) & 0.096 & 0.097 & 0.132 & 0.193 & 0.218 & 0.221 & 0.15 & 0.153 & 0.249 & 0.352 & 0.412 & 0.413 \\
\hline \multicolumn{13}{|l|}{ Control Varibales } \\
\hline Exchange Rate Regime & No & Yes & Yes & Yes & Yes & Yes & No & Yes & Yes & Yes & Yes & Yes \\
\hline GDP Controls & No & No & Yes & Yes & Yes & Yes & No & No & Yes & Yes & Yes & Yes \\
\hline EU \& euro membership & No & No & No & No & No & Yes & No & No & No & No & No & Yes \\
\hline Year FE & Yes & Yes & Yes & Yes & Yes & Yes & Yes & Yes & Yes & Yes & Yes & Yes \\
\hline Country-pair FE & Yes & Yes & Yes & Yes & Yes & Yes & Yes & Yes & Yes & Yes & Yes & Yes \\
\hline Country Time Trends & No & No & No & Yes & No & No & No & No & No & Yes & No & No \\
\hline Country-pair Time Trends & No & No & No & No & Yes & Yes & No & No & No & No & Yes & Yes \\
\hline Observations & 4,229 & 4,229 & 4,229 & 4,229 & 4,229 & 4,229 & 1831 & 1831 & 1831 & 1831 & 1831 & 1831 \\
\hline Country-pairs & 153 & 153 & 153 & 153 & 153 & 153 & 153 & 153 & 153 & 153 & 153 & 153 \\
\hline
\end{tabular}

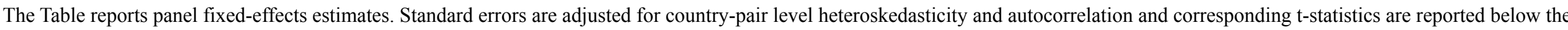

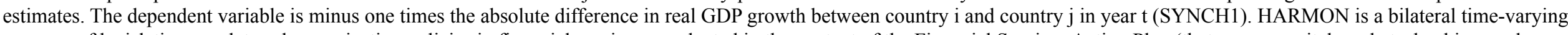
measure of legislative-regulatory harmonization policies in financial services, conducted in the context of the Financial Services Action Plan (that covers capital markets, banking, and insurance). The specifications in columns (1)-(6) are estimated in the full sample of years (1978-2006). The specifications in columns (7)-(12) are estimated over the period 1995-2006. Columns (2)-(6) and (8)-(12) include as control variable a bilateral time-varying measure of the flexibility of the exchange rate regime in the previous year, based on the "coarse" regime

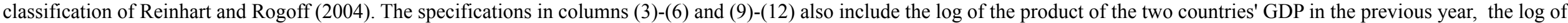
the product of the two countries' population in the previous year and the absolute value of the difference of the two countries' log GDP per capita in the previous year. The specifications in columns (6) and (12) also include as controls indicator variables that equal one when one of the two countries is a member of the EU or the euro area in the previous year and indicator variables that equal one when both countries are part of the EU and the euro area in the previous year. The specifications in columns (4) and (10) include a vector of country-specific linear time trends (coefficients not reported). The specification in columns (5)-(6) and (11)-(12) include a vector of country-pair specific linear time trends (coefficients not reported). All specifications include a vector of country-pair and year fixed-effects. 
Table 5: Legislative and Regulatory Harmonization in Financial Services, Banking Integration and

Business Cycle Synchronization:

Panel (Country-pair) Fixed-Effects Instrumental Variables Specifications

\begin{tabular}{|c|c|c|c|c|c|c|c|c|}
\hline & \multicolumn{4}{|c|}{ Full Sample Period } & \multicolumn{4}{|c|}{$1995-2006$} \\
\hline & (1) & (2) & (3) & (4) & $(5)$ & (6) & (7) & (8) \\
\hline \multicolumn{9}{|c|}{ Panel A: 2SLS Estimates: Dependent Variable is Business Cycle Synchronization (SYNCH1) } \\
\hline $\begin{array}{l}\text { Banking Integration } \\
(B A N K I N T 1)\end{array}$ & $\begin{array}{l}-0.5982 \\
(0.1458)\end{array}$ & $\begin{array}{l}-0.6829 \\
(0.1908)\end{array}$ & $\begin{array}{l}-0.6711 \\
(0.3063)\end{array}$ & $\begin{array}{l}-0.7734 \\
(0.3333)\end{array}$ & $\begin{array}{l}-0.7845 \\
(0.5010)\end{array}$ & $\begin{array}{l}-1.2105 \\
(0.7188)\end{array}$ & $\begin{array}{l}-0.7825 \\
(0.3799)\end{array}$ & $\begin{array}{r}-1.0550 \\
(0.4736)\end{array}$ \\
\hline & -4.10 & -3.58 & -2.19 & -2.32 & -1.57 & -1.68 & -2.06 & -2.23 \\
\hline $\begin{array}{l}\text { Exchange Rate Regime } \\
(E R C S U M)\end{array}$ & & $\begin{array}{c}-0.1155 \\
(0.0953) \\
-1.21\end{array}$ & & $\begin{array}{c}-0.1474 \\
(0.0865) \\
-1.71\end{array}$ & & $\begin{array}{l}-0.5165 \\
(0.2643) \\
-1.95\end{array}$ & & $\begin{array}{c}-0.4707 \\
(0.2011) \\
-2.34\end{array}$ \\
\hline
\end{tabular}

Panel B: 1st Stage Estimates: Dependent Variable is Banking Integration (BANKINT1)

\begin{tabular}{|c|c|c|c|c|c|c|c|c|}
\hline Financial Sector & 0.4046 & 0.3312 & 0.2300 & 0.2136 & 0.1935 & 0.1467 & 0.1698 & 0.1389 \\
\hline Harmonization & $(0.0834)$ & $(0.0754)$ & $(0.0533)$ & $(0.0519)$ & $(0.0473)$ & $(0.0453)$ & $(0.0380)$ & $(0.0358)$ \\
\hline$(H A R M O N)$ & 4.85 & 4.39 & 4.31 & 4.12 & 4.09 & 3.24 & 4.45 & 3.88 \\
\hline $\begin{array}{l}\text { Exchange Rate Regime } \\
(\text { ERCSUM) }\end{array}$ & & $\begin{array}{c}-0.2471 \\
(0.0787) \\
-3.14\end{array}$ & & $\begin{array}{c}-0.1028 \\
(0.0623) \\
-1.54\end{array}$ & & $\begin{array}{c}-0.2929 \\
(0.0617) \\
-4.75\end{array}$ & & $\begin{array}{c}-0.3138 \\
(0.0597) \\
-5.26\end{array}$ \\
\hline $\begin{array}{l}\text { First Stage } F \text {-score } \\
p \text {-value }\end{array}$ & $\begin{array}{c}23.52 \\
0.00\end{array}$ & $\begin{array}{c}19.31 \\
0.00\end{array}$ & $\begin{array}{c}18.59 \\
0.00\end{array}$ & $\begin{array}{c}16.97 \\
0.00\end{array}$ & $\begin{array}{c}16.71 \\
0.00\end{array}$ & $\begin{array}{c}10.49 \\
0.00\end{array}$ & $\begin{array}{c}19.96 \\
0.00\end{array}$ & $\begin{array}{c}15.03 \\
0.00\end{array}$ \\
\hline GDP Controls & No & No & Yes & Yes & No & Yes & Yes & Yes \\
\hline Year FE & Yes & Yes & Yes & Yes & Yes & Yes & Yes & Yes \\
\hline Country-pair FE & Yes & Yes & Yes & Yes & Yes & Yes & Yes & Yes \\
\hline Observations & 4229 & 4229 & 4229 & 4229 & 1831 & 1831 & 1831 & 1831 \\
\hline Country-pairs & 153 & 153 & 153 & 153 & 153 & 153 & 153 & 153 \\
\hline
\end{tabular}

Table 5 - Notes

The Table reports panel fixed-effect instrumental variable (two stage least-squares) coefficients. Panel A reports 2nd-Stage estimates. Panel B reports 1st-stage estimates and regression diagnostics. All models include a vector of country-pair fixed-effects and a vector of year fixedeffects (constants not reported). Standard errors are adjusted for country-pair level heteroskedasticity and autocorrelation and corresponding tstatistics are reported below the estimates. In all specifications the dependent variable in the second stage specification is minus one times the absolute difference in real GDP growth between country $i$ and country $j$ in year $t$ (SYNCH1).

The endogenous variable is the one year lagged value of the average of the logs of bilateral stocks of assets and liabilities normalized by the sum of the two countries' population in year $\mathrm{t}$ (BANKINT1). Banking Integration is instrucmented with a bilateral time-varying measure of legislative-regulatory harmonization policies in financial services, conducted in the context of the Financial Services Action Plan (HARMON). The specifications in columns (1)-(4) are estimated in the full sample of years (1978-2006). The specifications in columns (5)-(6) are estimated over the period 1995-2006. The specifications in columns (2), (4), (6), and (8) include as control variable a bilateral time-varying measure of the flexibility of the exchange rate regime in the previous year, based on the "coarse" regime classification of Reinhart and Rogoff (2004). The specifications in columns (3)-(4) and (7)-(8) also include as controls the log of the product of the two countries' GDP in the previous year, the $\log$ of the product of the two countries' population in the previous year and the absolute value of the difference of the two countries' log GDP per capita in the previous year. 
Table 6: Legislative and Regulatory Harmonization in Financial Services, Banking Integration and Business

Cycle Synchronization: Robustness Analysis

Panel (Country-pair) Fixed-Effects Specifications

Excluding Major Financial Crises

Excluding Major and Minor Financial Crises

(1)

(2)

(3)

(4)

(5)

(6)

Panel A: OLS Estimates: Dependent Variable is Business Cycle Synchronization (SYNCH1)

$\begin{array}{lcccccc}\text { Banking Integration } & -0.3656 & -0.2571 & -0.2577 & -0.3926 & -0.3004 & -0.3010 \\ (\text { BANKINTI) } & (0.0646) & (0.0641) & (0.0648) & (0.0643) & (0.0646) & (0.0659) \\ & -5.66 & -4.01 & -3.98 & -6.11 & -4.65 & -4.57 \\ \text { adjusted R-squared } & 0.125 & 0.140 & 0.140 & 0.140 & 0.158 & 0.158\end{array}$

Panel B: OLS Estimates: Dependent Variable is Business Cycle Synchronization (SYNCH1)

Financial Sector

Harmonization

$(H A R M O N)$

$-0.2247$

$-0.1555$

$-0.1557$

$-0.2370$

$-0.1653$

$-0.1632$

(0.0443)

(0.0686)

(0.0679)

(0.0428)

(0.0681)

(0.0673)

$-5.07$

$-2.29$

$-5.53$

$-2.43$

$-2.42$

adjusted R-squared

$0.090 \quad 0.130$

0.130

0.098

0.144

0.144

Panel C: 2SLS Estimates: Dependent Variable is Business Cycle Synchronization (SYNCH1)

\begin{tabular}{|c|c|c|c|c|c|c|}
\hline $\begin{array}{l}\text { Banking Integration } \\
(B A N K I N T 1)\end{array}$ & $\begin{array}{c}-0.5678 \\
(0.1505) \\
-3.77\end{array}$ & $\begin{array}{c}-0.6793 \\
(0.3121) \\
-2.18\end{array}$ & $\begin{array}{c}-0.7332 \\
(0.3382) \\
-2.17\end{array}$ & $\begin{array}{c}-0.6464 \\
(0.1751) \\
-3.69\end{array}$ & $\begin{array}{c}-0.8081 \\
(0.3588) \\
-2.25\end{array}$ & $\begin{array}{c}-0.8888 \\
(0.4066) \\
-2.19\end{array}$ \\
\hline $\begin{array}{l}\text { First Stage } F \text {-score } \\
p \text {-value }\end{array}$ & $\begin{array}{c}22.57 \\
0.00\end{array}$ & $\begin{array}{c}18.60 \\
0.00\end{array}$ & $\begin{array}{c}16.80 \\
0.00\end{array}$ & $\begin{array}{c}19.73 \\
0.00\end{array}$ & $\begin{array}{c}14.43 \\
0.00\end{array}$ & $\begin{array}{c}12.53 \\
0.00\end{array}$ \\
\hline $\begin{array}{l}\text { GDP Controls } \\
\text { ER Control }\end{array}$ & $\begin{array}{l}\text { No } \\
\text { No }\end{array}$ & $\begin{array}{l}\text { Yes } \\
\text { No }\end{array}$ & $\begin{array}{l}\text { Yes } \\
\text { Yes }\end{array}$ & $\begin{array}{l}\text { No } \\
\text { No }\end{array}$ & $\begin{array}{l}\text { Yes } \\
\text { No }\end{array}$ & $\begin{array}{l}\text { Yes } \\
\text { Yes }\end{array}$ \\
\hline $\begin{array}{l}\text { Year FE } \\
\text { Country-pair FE }\end{array}$ & $\begin{array}{l}\text { Yes } \\
\text { Yes }\end{array}$ & $\begin{array}{l}\text { Yes } \\
\text { Yes }\end{array}$ & $\begin{array}{l}\text { Yes } \\
\text { Yes }\end{array}$ & $\begin{array}{l}\text { Yes } \\
\text { Yes }\end{array}$ & $\begin{array}{l}\text { Yes } \\
\text { Yes }\end{array}$ & $\begin{array}{l}\text { Yes } \\
\text { Yes }\end{array}$ \\
\hline $\begin{array}{l}\text { Observations } \\
\text { Country-pairs }\end{array}$ & $\begin{array}{c}3909 \\
153\end{array}$ & $\begin{array}{c}3909 \\
153\end{array}$ & $\begin{array}{c}3909 \\
153\end{array}$ & $\begin{array}{c}3506 \\
153\end{array}$ & $\begin{array}{c}3506 \\
153\end{array}$ & $\begin{array}{c}3506 \\
153\end{array}$ \\
\hline
\end{tabular}

Table 6 - Notes

The Table reports least squares (in Panels A and B) and two stage least squares (in Panel C) panel fixed-effects estimates. In columns (1)-(3) we exclude observations when either country $i$ or country $j$ experience a major financial crisis in the period 1978-2006 using the financial crisis classification of Reinhart and Rogoff (2009). In columns (4)-(6) we exclude observations when either country $i$ or country $j$ experience a major or a minor financial crisis in the period 1978-2006 using the financial crisis classification of Reinhart and Rogoff (2009).

Panel A reports LS estimates associating business cycle synchronization (SYNCH1) with banking integration (BANKINT1) in the previous year. The dependent variable is minus one times the absolute difference in real GDP growth between country $i$ and country $j$ in year $t$ (SYNCH1). BANKINT1 denotes the one period lagged value of the average of the logs of bilateral stocks of assets and liabilities normalized by the sum of the two countries' population in year t. Panel B reports LS estimates associating business cycle synchronization (SYNCH1) with a bilateral time-varying measure of legislative-regulatory harmonization policies in financial services, conducted in the context of the Financial Services Action Plan that covers capital markets, banking, and insurance (HARMON).

Panel C reports panel fixed-effect instrumental variable (two stage least-squares) estimates. The dependent variable in the second stage is minus one times the absolute difference in real GDP growth between country $i$ and country $j$ in year $t$ (SYNCH1). The endogenous variable is the one year lagged value of the average of the logs of bilateral stocks of assets and liabilities normalized by the sum of the two countries' population in year $t$ (BANKINT1). Banking Integration is instrumented with a bilateral time-varying measure of legislative-regulatory harmonization policies in financial services, conducted in the context of the Financial Services Action Plan (HARMON).

In all panels standard errors are adjusted for country-pair level heteroskedasticity and autocorrelation and corresponding t-statistics are reported below the estimates. The specifications in columns (2), (3), (5) and (6) include the log of the product of the two countries' GDP in the previous year, the log of the product of the two countries' population in the previous year and the absolute value of the difference of the two countries' log GDP per capita in the previous year. The specifications in columns (3) and (6) also include as control variable a bilateral time-varying measure of the flexibility of the exchange rate regime in the previous year, based on the "coarse" regime classification of Reinhart and Rogoff (2004). 
Table 7a: Banking Integration and Business Cycle Synchronization Role of Liabilities and Assets

Dependent Variable

Difference in Real GDP p.c. growth between country $i$ and country $j$

(1)

(2)

(3)

(4)

(5)

(6)

$\begin{array}{lccc}\text { Change in the Overall Net } & -0.1304 & -0.1251 & -0.1181 \\ \text { Asset Position } & (0.0235) & (0.0226) & (0.0225) \\ & -5.55 & -5.54 & -5.26\end{array}$

Change in Assets
of country $i$ to country $j$

Change in Assets

of country $j$ to country $i$

Year Fixed-Effects
Country-pair Fixed Effects
Trends

R-squared (within)

Observations

Country-pairs

\begin{tabular}{cccccc} 
& & & -0.1484 & -0.1405 & -0.1381 \\
& & & $(0.0343)$ & $(0.0326)$ & $(0.0324)$ \\
& & -4.33 & -4.30 & -4.26 \\
& & & & & \\
& & & 0.1118 & 0.1093 & 0.0976 \\
& & & $(0.0295)$ & $(0.0274)$ & $(0.0278)$ \\
& & & 3.79 & 3.98 & 3.51 \\
Yes & Yes & Yes & Yes & Yes & Yes \\
Yes & Yes & Yes & Yes & Yes & Yes \\
No & Country & Country-pair & No & Country & Country-pair \\
& & & & & \\
0.024 & 0.046 & 0.118 & 0.024 & 0.047 & 0.118 \\
& & & & & \\
4,229 & 4,229 & 4,229 & 4,229 & 4,229 & 4,229 \\
153 & 153 & 153 & 153 & 153 & 153 \\
\hline
\end{tabular}

The Table reports panel fixed-effect (within) coefficients that include both a vector of country-pair fixed-effects and a vector of year/period fixed-effects; in addition, in Column (2) and (5) there are also country specific time trends, and in Column (3) and (6) there are country-pair specific time trends. Standard errors are adjusted for country-pair level heteroskedasticity and autocorrelation. In all the specifications the dependent variable is difference in real GDP p.c. growth between country $i$ and country $j$. These models are based on annual observations that cover the period 1978-2006. Change in assets of country $j$ to country $i$ denotes the change in log assets of country $j$ in country $i$ plus log liabilities of country $i$ to country $j$, whereas Change in overall asset net positions denotes change in assets of country $i$ to country $j$ minus change in assets of country $j$ to country $i$. The Data Appendix gives details on the construction and the sources of all variables. The Table also gives the number of country-pairs, the number of observations, and the within R-squared. 
Table 7b: Ouput Growth and Changes in Net Foreign Asset Positions Panel (Country-Pair) Fixed-Effects Specifications

\begin{tabular}{|c|c|c|c|c|c|c|c|c|c|}
\hline \multirow[t]{2}{*}{ dependent variable } & \multicolumn{3}{|c|}{$\begin{array}{l}\text { Change in Asset Position } \\
\text { of Country i to Country j }\end{array}$} & \multicolumn{3}{|c|}{$\begin{array}{l}\text { Change in Asset Position } \\
\text { of Country } \mathrm{j} \text { to Country } \mathrm{i}\end{array}$} & \multicolumn{3}{|c|}{$\begin{array}{l}\text { Change in the Overall } \\
\text { Net Asset Position }\end{array}$} \\
\hline & (1) & (2) & (3) & (4) & $(5)$ & $(6)$ & (7) & $(8)$ & (9) \\
\hline \multirow[t]{2}{*}{$\begin{array}{l}\text { Difference in Real GDP p.c. growth } \\
\text { between country } i \text { and country } j\end{array}$} & $\begin{array}{l}-0.0216 \\
(0.0059)\end{array}$ & $\begin{array}{l}-0.0207 \\
(0.0056)\end{array}$ & $\begin{array}{l}-0.0222 \\
(0.0059)\end{array}$ & $\begin{array}{c}0.0134 \\
(0.0054)\end{array}$ & $\begin{array}{c}0.0136 \\
(0.0050)\end{array}$ & $\begin{array}{c}0.0126 \\
(0.0055)\end{array}$ & $\begin{array}{l}-0.0350 \\
(0.0063)\end{array}$ & $\begin{array}{l}-0.0343 \\
(0.0061)\end{array}$ & $\begin{array}{l}-0.0348 \\
(0.0065)\end{array}$ \\
\hline & -3.67 & -3.71 & -3.75 & 2.47 & 2.70 & 2.30 & -5.56 & -5.59 & -5.31 \\
\hline R-squared (within) & 0.055 & 0.066 & 0.075 & 0.05 & 0.054 & 0.063 & 0.014 & 0.016 & 0.024 \\
\hline Year FE & Yes & Yes & Yes & Yes & Yes & Yes & Yes & Yes & Yes \\
\hline Country-pair FE & Yes & Yes & Yes & Yes & Yes & Yes & Yes & Yes & Yes \\
\hline Country Time Trends & No & Yes & No & No & Yes & No & No & Yes & No \\
\hline Country-pair Time Trends & No & No & Yes & No & No & Yes & No & No & Yes \\
\hline Observations & 4,229 & 4,229 & 4,229 & 4,229 & 4,229 & 4,229 & 4,229 & 4,229 & 4,229 \\
\hline Country-pairs & 153 & 153 & 153 & 153 & 153 & 153 & 153 & 153 & 153 \\
\hline
\end{tabular}

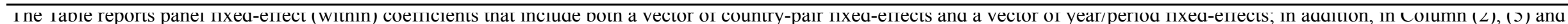
(7) there are also country specific time trends, and in Column (3), (6) and (9) there are country-pair specific time trends. Standard errors are adjusted for country-pair level

heteroskedasticity and autocorrelation. In all the specifications the independent variable is difference in real GDP p.c. growth between country $i$ and country $j$. These models are based on annual observations that cover the period 1978-2006. The dependent variable are: Change in assets of country $i$ to country $j$ (which denotes the change in log assets of country $i$ in country $j$ plus $\log$ liabilities of country $j$ to country i) in Column (1) to (3); Change in assets of country $j$ to country $i$ (which denotes the change in log assets of country $j$ in country i plus log

liabilities of country i to country $j$ ) in Column (4) to (6); and Change in overall asset net positions (which denotes change in assets of country $i$ to country $j$ minus change in assets of country j to country i) in Column (7) to (9). The Data Appendix gives details on the construction and the sources of all variables. The Table also gives the number of country-pairs and the number of observations. 
Figure 1: GDP Synchronization across Time

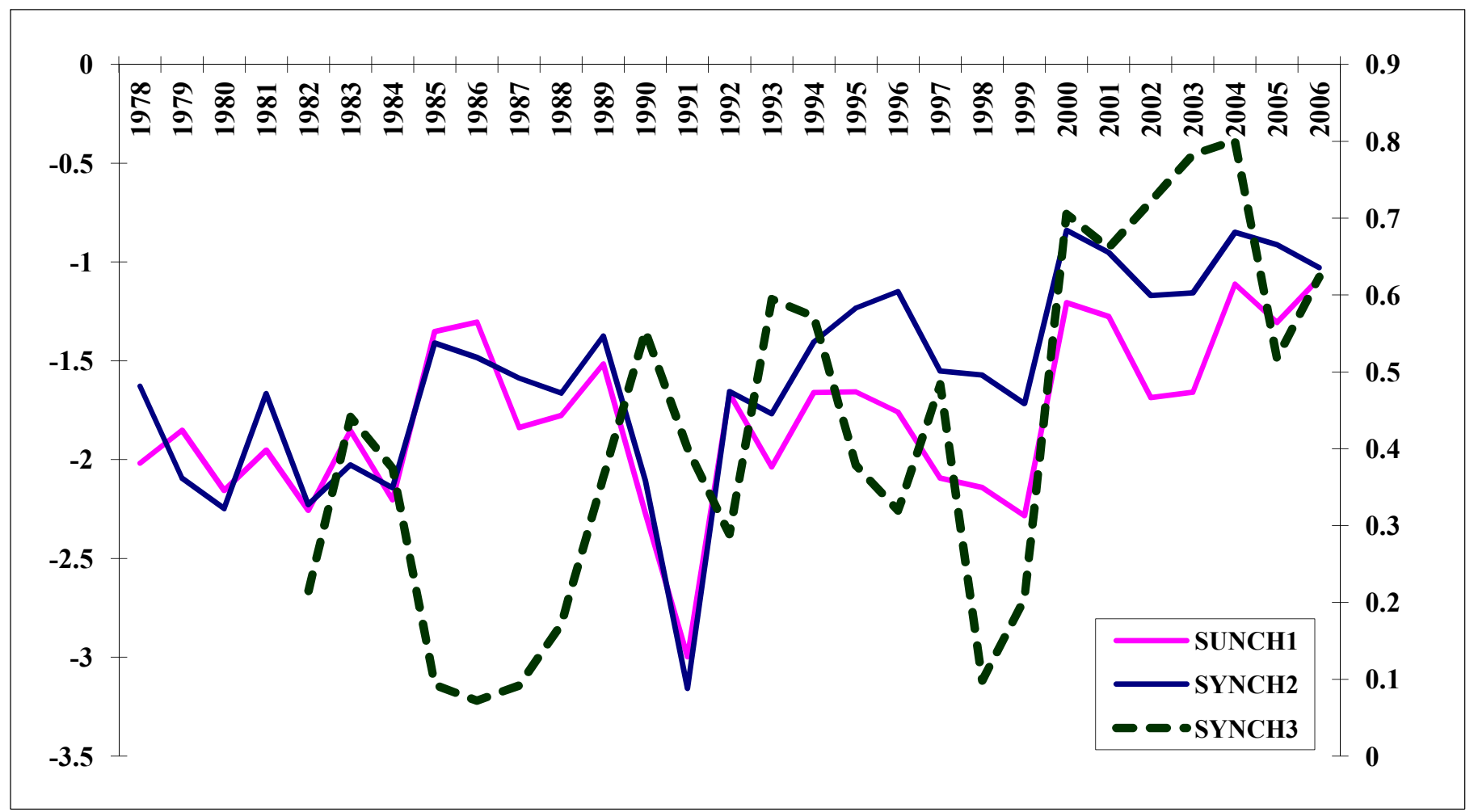

Figure 1 plots the evolution of the average value of each of the three synchronization measures employed in the empirical analysis across the 1978-2006 period. For each year the average is estimated across 153 country pairs (our sample spans 18 countries). SYNCH1 is the negative value of the absolute difference in real GDP growth between country $i$ and country $j$ in year $t$. SYNCH2 is the negative of the absolute difference of residual real GDP growth between country $i$ and country $j$ in year $t$. SYNCH3 is the correlation of the cyclical component of real GDP between country $i$ and $j$ in each five-year period (estimated with the Baxter and King Band-Pass filter $(2,8))$. The correlation is estimated with a five-year rolling window. 


\section{Figure 2: Banking Integration over Time}

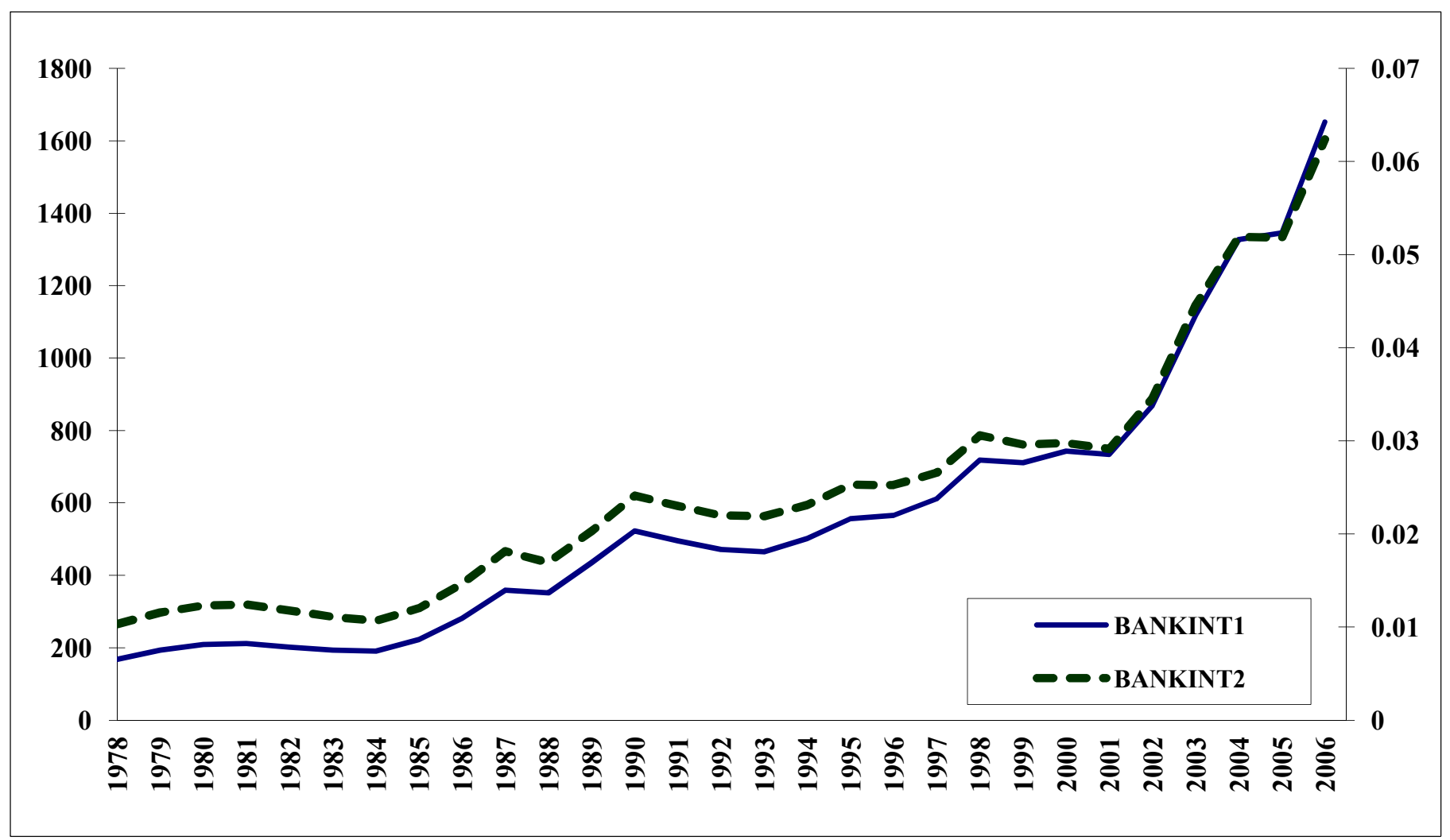

Figure 2 plots the evolution of the two banking integration measures, expressed in levels (solid lines) and in logs (dashed lines). BANKINT1 denotes the average of the logs of bilateral stocks of assets and liabilities normalized by the sum of the two countries' population. BANKINT2 denotes the average of the logs of bilateral stocks of assets and liabilities normalized by the sum of the two countries' GDP. 
Figure 3:

\section{Legislative/Regulatory Harmonization in Financial Services and Banking Integration}

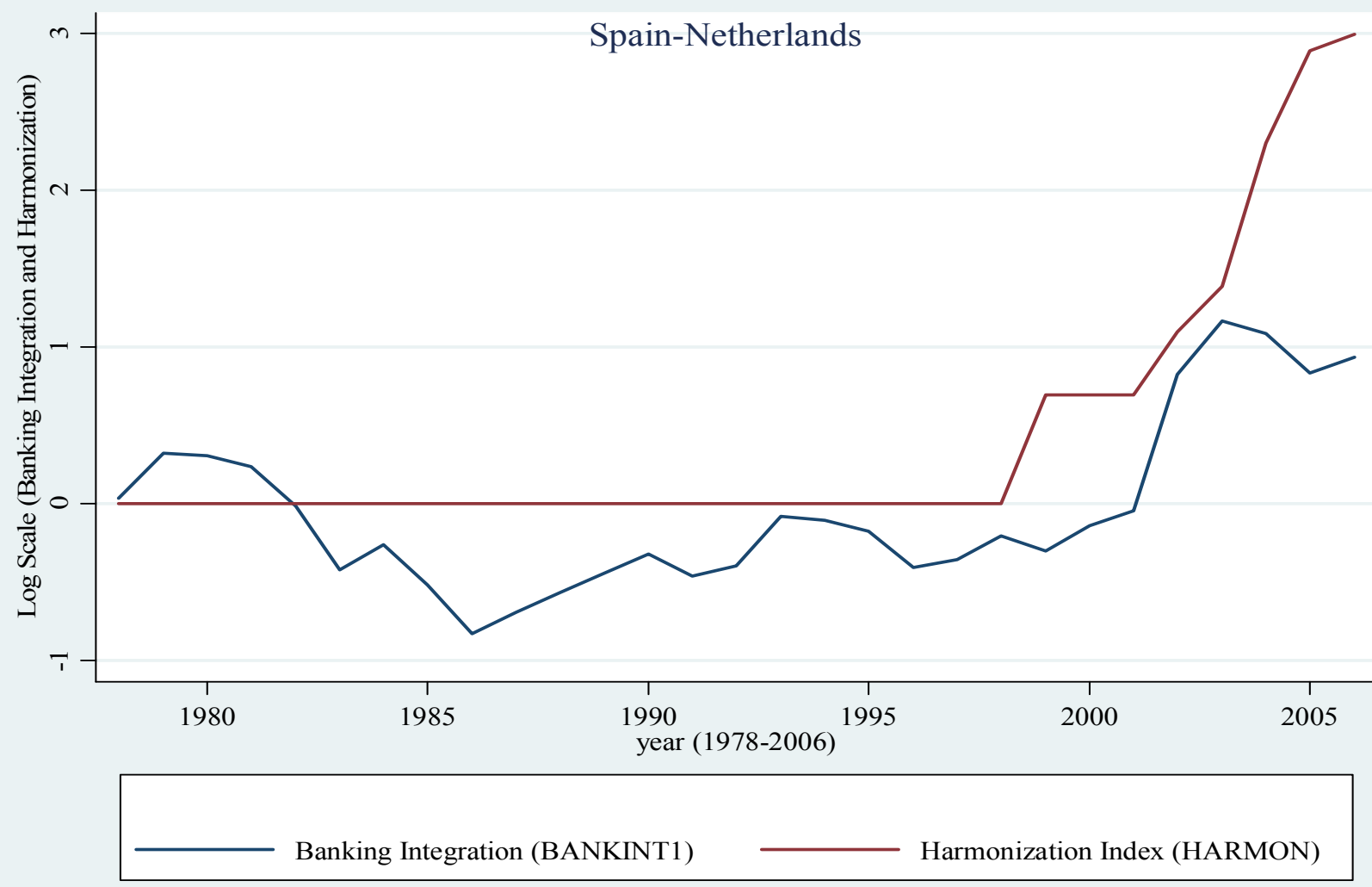

Figure 3 plots the within country-pair and within year evolution over time of banking integration (BANKINT1) and the legislative/regulatory harmonization index in financial services (HARMON) between Spain and Netherlands. 
Appendix Table 1: Cross-Sectional and Panel Estimates

Illustrating the Differences

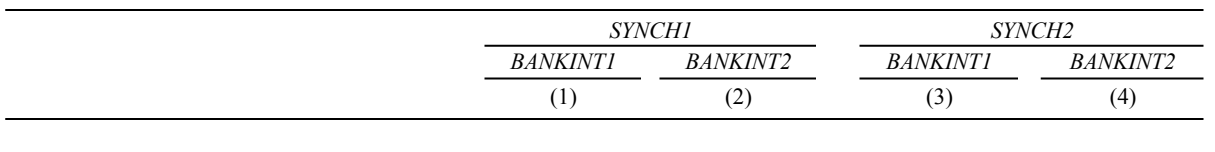

Panel A: Cross-Sectional Estimates with Year Fixed-Effects

$\begin{array}{lcccc}\text { Banking Integration } & 0.0597 & 0.0849 & 0.0645 & 0.0910 \\ (B A N K I N T) & (0.0224) & (0.0185) & (0.0230) & (0.0189) \\ & 2.67 & 4.58 & 2.80 & 4.82 \\ \text { R-squared } & 0.081 & 0.143 & 0.082 & 0.144\end{array}$

Panel B: Panel (country-pair) Fixed-Effects Estimates with a Single Common Time Trend

$\begin{array}{lcccc}\text { Banking Integration } & -0.4204 & -0.1254 & -0.4286 & -0.1267 \\ (\text { BANKINT) } & (0.0577) & (0.0294) & (0.0594) & (0.0293) \\ & -7.28 & -4.27 & -7.21 & -4.32 \\ \text { R-squared } & 0.062 & 0.070 & 0.062 & 0.069\end{array}$

Panel C: Panel (country-pair) Fixed-Effects Estimates with a Country Specific Time Trends

$\begin{array}{lcccc}\text { Banking Integration } & -0.1862 & -0.1970 & -0.1871 & -0.1926 \\ \text { (BANKINT) } & (0.0506) & (0.0404) & (0.0513) & (0.0401) \\ & -3.68 & -4.88 & -3.65 & -4.80 \\ & & & & 0.090\end{array}$

Panel D: Panel (country-pair) Fixed-Effects Estimates with Country-pair Specific Time Trends

$\begin{array}{lcccc}\text { Banking Integration } & -0.2614 & -0.2614 & -0.2634 & -0.2574 \\ \text { (BANKINT) } & (0.0639) & (0.0538) & (0.0650) & (0.0534) \\ & -4.09 & -4.86 & -4.05 & -4.82 \\ \text { R-squared } & 0.138 & 0.106 & 0.138 & 0.105\end{array}$

Panel E: Panel (country-pair) Fixed-Effects Estimates with Year Fixed-Effects and Country Specific Time Trends

$\begin{array}{lcccc}\text { Banking Integration } & -0.0940 & -0.0995 & -0.0989 & -0.0995 \\ (B A N K I N T) & (0.0510) & (0.0386) & (0.0519) & (0.0391) \\ & -1.84 & -2.58 & -1.91 & -2.54 \\ & & & & 0.184 \\ \text { R-squared } & 0.184 & 0.166 & 0.166\end{array}$

Panel F: Panel (country-pair) Fixed-Effects Estimates with Year Fixed-Effects and Country-pair Specific Time Trends

\begin{tabular}{lcccc} 
Banking Integration & -0.1371 & -0.1276 & -0.1441 & -0.1290 \\
(BANKINT) & $(0.0658)$ & $(0.0522)$ & $(0.0671)$ & $(0.0531)$ \\
& -2.08 & -2.44 & -2.15 & -2.43 \\
R-squared & & & 0.211 & 0.181 \\
& 0.211 & 0.181 & & 4,229 \\
Observations & & & 4,229 & 153 \\
Country-pairs & 4,229 & 4,229 & 153 & 153 \\
\hline
\end{tabular}

Panel A reports cross-sectional (between) coefficients with year fixed-effects . Panel B reports panel (country-pair) fixed-effect estimates that include a single (common to all country-pairs) linear time trend. Panel C reports panel (country-pair) fixed-effect estimates that include country-specific linear time trends. Panel D reports panel (country-pair) fixed-effect estimates that include country-pair specific linear time trends. Panel E reports panel (country-pair) fixed-effect estimates that include time (year) fixed-effects and country specific linear time trends. Panel F reports panel (country-pair) fixed-effect estimates that include time (year) fixed-effects and country-pair specific linear time trends.

In all specifications standard errors are adjusted for country-pair level heteroskedasticity and autocorrelation. In specifications (1) and (3) the dependent variable is minus one times the absolute difference in real GDP growth between country $i$ and country $j$ in year $t$ (SYNCHI). In specifications (2) and (4) the dependent variable is minus one times the absolute difference of residual real GDP growth between country $i$ and country $j$ in year $t$ (SYNCH2). All models are based on annual observations that cover the period 1978-2006.

$B A N K I N T 1$ denotes the one period lagged value of the average of the logs of bilateral stocks of assets and liabilities normalized by the sum of the two countries' population in year $t$. BANKINT2 denotes the one year lagged value of the average of the logs of bilateral stocks of assets and liabilities normalized by the sum of the two countries' GDP in year t. The Data Appendix and Section 3 give details on the construction and the sources of all variables. The Table also gives the number of country-pairs, the number of observations, the between R-squared (for the cross-sectional models) and the within R-squared (for the panel fixed-effect specifications). 


\section{Appendix Table 2: Banking Integration and Business Cycle Synchronization over the Long-Run Cross-Sectional and Panel (Country-Pair) Fixed-Effects Specifications}

Dependent Variable: Output Synchronization (SYNCH3)

BANKINT1 $\quad$ BANKINT2

(1)

(2)

(3)

(4)

\section{Panel A: Cross-Sectional ("Between") Estimates}

$\begin{array}{lcccc}\text { Banking Integration } & 0.0359 & 0.0246 & 0.0398 & 0.0297 \\ (\text { BANKINT) } & (0.009) & (0.0097) & (0.0085) & (0.0096) \\ & 4.12 & 2.52 & 4.66 & 3.09 \\ \text { Trade } & & & & 2.3686 \\ (\text { TRADE }) & & 2.6738 & (1.0996) & (1.0916) \\ & & 2.43 & & 2.17 \\ \text { R-squared (between) } & 0.109 & 0.145 & 0.135 & 0.164\end{array}$

Panel B: Panel Estimates ("Within") with Country-Pair and Year/Period Fixed-Effects

Banking Integration

(BANKINT)

Trade

$(T R A D E)$

R-2 (within)

Observations

Country-pairs

$$
-0.0967
$$

0.413

282

141
$-0.0968$
(0.0332)
$-2.91$

$-0.7101$

(4.4868)

$-0.16$

0.413

282

141
-0.0908
$(0.0338)$
-2.68

$-0.0910$

(0.0339)

$-2.68$

$-0.8382$

(4.4800)

$-0.19$

0.405

0.405

282

282

141

Panel A reports cross-sectional (between) coefficients. Panel B reports panel fixed-effect (within) coefficients that include a vector of country-pair fixed-effects and a vector of period fixed-effects. In the panel models in Panel B standard errors are adjusted for country-pair level heteroskedasticity and autocorrelation. In all specifications the dependent variable is the correlation of the cyclical component of real between country i and j, estimated over a 14-year period ( $\mathrm{SYNCH3}$; estimated with the Baxter and King Band-Pass filter (2,8)).

BANKINT1 is the average of the logs of bilateral stocks of assets and liabilities normalized by the sum of the two countries' population in year $t$. BANKINT2 is the average of the logs of bilateral stocks of assets and liabilities normalized by the sum of the two countries' GDP in year t. TRADE denotes the log of sum of real bilateral imports and exports of both countries as a share of the two countries' GDP. In all columns we use the values of BANKINT1, BANKINT2, and TRADE in the beginning of each of the two periods. The Data Appendix and Section 3 give details on the construction and the sources of all variables. The Table also gives the number of country-pairs, the number of observations, the between R-squared (for the cross-sectional models) and the within R-squared (for the panel fixed-effect specifications). 


\section{Appendix Table 3: Legislative Harmonization in Financial Services and Business Cycle Synchronization Sensitivity Analysis}

\begin{tabular}{|c|c|c|c|c|c|c|}
\hline & \multicolumn{2}{|c|}{$\begin{array}{c}\text { Unilateral } \\
\text { Transposition } \\
\end{array}$} & \multicolumn{2}{|c|}{ Stock Market Turnover } & \multicolumn{2}{|c|}{$\begin{array}{l}\text { Stock Market } \\
\text { Capitalization } \\
\end{array}$} \\
\hline & (1) & (2) & (3) & (4) & (5) & (6) \\
\hline $\begin{array}{l}\text { Financial Sector Harmonization } \\
(H A R M O N)\end{array}$ & $\begin{array}{c}-0.2994 \\
(0.0939) \\
-3.19\end{array}$ & $\begin{array}{c}-0.2177 \\
(0.1041) \\
-2.09\end{array}$ & $\begin{array}{c}-0.2772 \\
(0.0604) \\
-4.59\end{array}$ & $\begin{array}{c}-0.1906 \\
(0.0619) \\
-3.08\end{array}$ & $\begin{array}{c}-0.3025 \\
(0.0574) \\
-5.27\end{array}$ & $\begin{array}{c}-0.1685 \\
(0.0597) \\
-2.82\end{array}$ \\
\hline FSAP in Country $i$ & $\begin{array}{c}0.1520 \\
(0.0935) \\
1.63\end{array}$ & $\begin{array}{c}0.0356 \\
(0.0928) \\
0.38\end{array}$ & & & & \\
\hline FSAP in Country $j$ & $\begin{array}{c}0.1772 \\
(0.0920) \\
1.93\end{array}$ & $\begin{array}{c}-0.0093 \\
(0.0938) \\
-0.10\end{array}$ & & & & \\
\hline Stock Market Turnover in Country $i$ & & & $\begin{array}{c}-0.0004 \\
(0.0011) \\
-0.33\end{array}$ & $\begin{array}{c}-0.0006 \\
(0.0013) \\
-0.44\end{array}$ & & \\
\hline Stock Market Turnover in Country $j$ & & & $\begin{array}{c}0.0002 \\
(0.0008) \\
0.29\end{array}$ & $\begin{array}{c}-0.0024 \\
(0.0009) \\
-2.60\end{array}$ & & \\
\hline Stock Market Capitalization in Country $i$ & & & & & $\begin{array}{c}0.0034 \\
(0.0011) \\
3.23\end{array}$ & $\begin{array}{c}0.0027 \\
(0.0012) \\
2.17\end{array}$ \\
\hline Stock Market Coapitalization in Country $j$ & & & & & $\begin{array}{c}0.0036 \\
(0.0012) \\
3.08\end{array}$ & $\begin{array}{c}0.0023 \\
(0.0013) \\
1.80\end{array}$ \\
\hline Year FE & Yes & Yes & Yes & Yes & Yes & Yes \\
\hline Country-pair FE & Yes & Yes & Yes & Yes & Yes & Yes \\
\hline Country-specific trends & Yes & No & Yes & No & Yes & No \\
\hline Controls & No & Yes & No & Yes & No & Yes \\
\hline R-squared (within) & 0.185 & 0.227 & 0.313 & 0.231 & 0.305 & 0.213 \\
\hline Observations & 4229 & 1831 & 2593 & 1831 & 2624 & 1814 \\
\hline Country-pairs & 153 & 153 & 153 & 153 & 153 & 153 \\
\hline
\end{tabular}

\section{Appendix Table 3 - Notes}

The Table reports panel fixed-effect coefficients. All models include a vector of country-pair fixed-effects, a vector of year fixed-effects and country-specific linear time trends. The specifications in even numbered-columns also include a vector of country-specific linear time trends. Standard errors are adjusted for country-pair level heteroskedasticity and autocorrelation and corresponding t-statistics are reported below the estimates. In all specifications the dependent variable is minus one times the absolute difference in real GDP growth between country $\mathrm{i}$ and country $\mathrm{j}$ in year $\mathrm{t}$ (SYNCH1).

HARMON is a bilateral time-varying measure of legislative-regulatory harmoninzation policies in financial services, conducted in the context of the Financial Services Action Plan (that covers capital markets, banking, and insurance). The specifications in columns (1), (3), and (5) are estimated in the full sample of years (1978-2006). The specifications in columns (2), (4), and (6) are estimated over the period 1995-2006. Columns (2), (4), and (6) include as control variables: (i) a bilateral time-varying measure of the flexibility of the exchange rate regime in the previous year, based on the "coarse" regime classification of Reinhart and Rogoff (2004); (ii) the log of the product of the two countries' GDP in the previous year; (iii) two indicator variables that equal one when one of the two countries is a member of the EU or the euro area respectively; (iv) two indicator variables that euqal one when both countries are part of the EU and the euro area in the previous year.

In columns (1) and (2) we include in the set of explanatory variables a country-time-varying index that reflects the degree of legislative harmonization policies in countries $i$ and $j$ in the previous year. In columns (3) and (4) we include stock market turnover in countries $i$ and $j$ in the previous year. In columns (5) and (6) we include stock market capitalization in countries $i$ and $j$ in the previous year. 
Appendix Table 4: Legislative and Regulatory Harmonization in Financial Services and Cross-Border

Banking Activities:

Panel (Country-pair) Fixed-Effects LS Specifications

\begin{tabular}{|c|c|c|c|c|c|c|c|c|}
\hline & \multicolumn{4}{|c|}{ Full Sample Period } & \multicolumn{4}{|c|}{$1995-2006$} \\
\hline & (1) & (2) & (3) & (4) & (5) & (6) & (7) & (8) \\
\hline \multicolumn{9}{|l|}{ Financial Sector } \\
\hline \multirow{3}{*}{$\begin{array}{l}\text { Harmonization } \\
(H A R M O N)\end{array}$} & 0.4125 & 0.3257 & 0.3090 & 0.1140 & 0.1605 & 0.1521 & 0.1413 & 0.0772 \\
\hline & $(0.1295)$ & $(0.1081)$ & $(0.1061)$ & $(0.0986)$ & $(0.0742)$ & $(0.0617)$ & $(0.0597)$ & $(0.0593)$ \\
\hline & 3.19 & 3.01 & 2.91 & 1.16 & 2.16 & 2.47 & 2.37 & 1.30 \\
\hline \multirow[t]{3}{*}{ FSAP in Country $i$} & -0.028 & 0.0343 & -0.0160 & 0.0899 & -0.0169 & -0.0086 & -0.0471 & -0.0093 \\
\hline & $(0.0931)$ & $(0.0923)$ & $(0.0907)$ & $(0.0847)$ & $(0.0604)$ & $(0.0517)$ & $(0.0498)$ & $(0.0468)$ \\
\hline & -0.3 & 0.37 & -0.18 & 1.06 & -0.28 & -0.17 & -0.95 & -0.20 \\
\hline \multirow[t]{3}{*}{ FSAP in Country $j$} & 0.0223 & 0.0972 & 0.0598 & 0.1468 & 0.0886 & 0.0612 & 0.0404 & 0.0721 \\
\hline & $(0.0957)$ & $(0.0957)$ & $(0.0939)$ & $(0.0892)$ & $(0.0648)$ & 0.0554 & 0.0539 & $(0.0542)$ \\
\hline & 0.23 & 1.02 & 0.64 & 1.65 & 1.37 & 1.11 & 0.75 & 1.33 \\
\hline \multirow{3}{*}{$\begin{array}{l}\text { Exchange Rate Regime } \\
(E R C S U M)\end{array}$} & & & -0.2392 & -0.2036 & & & -0.2986 & -0.2948 \\
\hline & & & $(0.0658)$ & $(0.0617)$ & & & $(0.0600)$ & $(0.0609)$ \\
\hline & & & -3.64 & -3.30 & & & -4.98 & -4.84 \\
\hline GDP Control & No & Yes & Yes & Yes & No & Yes & Yes & Yes \\
\hline EU and EURO Controls & No & No & Yes & Yes & No & No & Yes & Yes \\
\hline Year FE & Yes & Yes & Yes & Yes & Yes & Yes & Yes & Yes \\
\hline Country-pair FE & Yes & Yes & Yes & Yes & Yes & Yes & Yes & Yes \\
\hline R-squared (within) & 0.479 & 0.627 & 0.635 & 0.652 & 0.273 & 0.412 & 0.436 & 0.449 \\
\hline Observations & 4229 & 4229 & 4229 & 4229 & 1831 & 1831 & 1831 & 1831 \\
\hline Country-pairs & 153 & 153 & 153 & 153 & 153 & 153 & 153 & 153 \\
\hline
\end{tabular}

Appendix Table 4 - Notes

The Table reports panel fixed-effect LS estimates. All models include a vector of country-pair fixed-effects and a vector of year fixed-effects. Standard errors are adjusted for country-pair level heteroskedasticity and autocorrelation and corresponding t-statistics are reported below the estimates. In all specifications the dependent variable is the average of the logs of bilateral stocks of assets and liabilities normalized by the sum of the two countries' population in year t (BANKINT1).

HARMON is a bilateral time-varying measure of legislative-regulatory harmoninzation policies in financial services, conducted in the context of the Financial Services Action Plan (that covers capital markets, banking, and insurance). The specifications in columns (1)-(4) are estimated in the full sample of years (1978-2006). The specifications in columns (5)-(8) are estimated over the period 1995-2006. Columns (3)-(4) and (7)-(8) include as control variable a bilateral time-varying measure of the flexibility of the exchange rate regime in the previous year, based on the "coarse" regime classification of Reinhart and Rogoff (2004). The specifications in columns (2)-(4) and (6)-(8) also include the log of the product of the two countries' GDP in the previous year. Columns (4) and (8) also include indicator variables that equal one when one of the two countries is a member of the EU or the euro area in the previous year and indicator variables that euqal one when both countries are part of the EU and the euro area in the previous year. The Data Appendix and Section 3 gives details on the construction and the sources of all variables. 
Appendix Table 5: Banking Integration and Business Cycle Synchronization

Dynamic Panel (Country-Pair) Fixed-Effects Specifications

\begin{tabular}{|c|c|c|c|c|c|c|c|c|}
\hline & \multicolumn{2}{|c|}{ BANKINT1 } & \multicolumn{2}{|c|}{ BANKINT2 } & \multicolumn{2}{|c|}{ BANKINT1 } & \multicolumn{2}{|c|}{ BANKINT2 } \\
\hline & SYNCH1 & SYNCH2 & SYNCH1 & SYNCH2 & SYNCH3 & SYNCH3 & SYNCH3 & SYNCH3 \\
\hline & (1) & (2) & (3) & (4) & $(5)$ & (6) & (7) & $(8)$ \\
\hline $\begin{array}{l}\text { Lag (1) Banking Integration } \\
(B A N K I N T)\end{array}$ & $\begin{array}{c}-0.0759 \\
(0.0423) \\
-1.79\end{array}$ & $\begin{array}{c}-0.0898 \\
(0.0343) \\
-2.62\end{array}$ & $\begin{array}{c}-0.0785 \\
(0.0431) \\
-1.82\end{array}$ & $\begin{array}{c}-0.0885 \\
(0.0349) \\
-2.54\end{array}$ & $\begin{array}{c}-0.1113 \\
(0.0473) \\
-2.36\end{array}$ & $\begin{array}{c}-0.0771 \\
(0.0361) \\
-2.14\end{array}$ & $\begin{array}{c}-0.1091 \\
(0.0475) \\
-2.3\end{array}$ & $\begin{array}{c}-0.0764 \\
(0.0364) \\
-2.1\end{array}$ \\
\hline $\begin{array}{l}\text { Lag (1) Synchronization } \\
(S Y N C H 2)\end{array}$ & $\begin{array}{c}0.2081 \\
(0.0173) \\
12.06\end{array}$ & $\begin{array}{c}0.1501 \\
(0.0199) \\
7.55\end{array}$ & $\begin{array}{c}0.2079 \\
(0.0173) \\
12.05\end{array}$ & $\begin{array}{c}0.1500 \\
(0.0199) \\
7.54\end{array}$ & $\begin{array}{c}0.2045 \\
(0.0175) \\
11.67\end{array}$ & $\begin{array}{c}0.1516 \\
(0.0204) \\
7.42\end{array}$ & $\begin{array}{c}0.2045 \\
(0.0175) \\
11.67\end{array}$ & $\begin{array}{c}0.1516 \\
(0.0204) \\
7.42\end{array}$ \\
\hline $\begin{array}{l}\text { Long-run effect - Banking Integration } \\
F \text {-score } \\
p \text {-value }\end{array}$ & $\begin{array}{c}-0.0958 \\
3.22 \\
0.07\end{array}$ & $\begin{array}{c}-0.1057 \\
6.95 \\
0.01\end{array}$ & $\begin{array}{c}-0.0991 \\
3.33 \\
0.07\end{array}$ & $\begin{array}{c}-0.1041 \\
6.55 \\
0.01\end{array}$ & $\begin{array}{c}-0.1399 \\
5.59 \\
0.02\end{array}$ & $\begin{array}{c}-0.0909 \\
4.68 \\
0.03\end{array}$ & $\begin{array}{c}-0.1371 \\
5.31 \\
0.03\end{array}$ & $\begin{array}{c}-0.0901 \\
4.52 \\
0.04\end{array}$ \\
\hline $\begin{array}{l}\text { Year FE } \\
\text { Country-pair FE } \\
\text { Country-specific trends } \\
\text { Lag Log Product of GDPs }\end{array}$ & $\begin{array}{l}\text { Yes } \\
\text { Yes } \\
\text { Yes } \\
\text { No }\end{array}$ & $\begin{array}{l}\text { Yes } \\
\text { Yes } \\
\text { Yes } \\
\text { No }\end{array}$ & $\begin{array}{l}\text { Yes } \\
\text { Yes } \\
\text { Yes } \\
\text { No }\end{array}$ & $\begin{array}{l}\text { Yes } \\
\text { Yes } \\
\text { Yes } \\
\text { No }\end{array}$ & $\begin{array}{l}\text { Yes } \\
\text { Yes } \\
\text { Yes } \\
\text { Yes }\end{array}$ & $\begin{array}{l}\text { Yes } \\
\text { Yes } \\
\text { Yes } \\
\text { Yes }\end{array}$ & $\begin{array}{l}\text { Yes } \\
\text { Yes } \\
\text { Yes } \\
\text { Yes }\end{array}$ & $\begin{array}{l}\text { Yes } \\
\text { Yes } \\
\text { Yes } \\
\text { Yes }\end{array}$ \\
\hline $\begin{array}{l}\text { R-squared (within) } \\
\text { Observations } \\
\text { Country-pairs }\end{array}$ & $\begin{array}{c}0.220 \\
4,229 \\
153\end{array}$ & $\begin{array}{c}0.186 \\
4,229 \\
153\end{array}$ & $\begin{array}{c}0.220 \\
4,229 \\
153\end{array}$ & $\begin{array}{c}0.187 \\
4,229 \\
153\end{array}$ & $\begin{array}{c}0.222 \\
4,229 \\
153\end{array}$ & $\begin{array}{c}0.188 \\
4,229 \\
153\end{array}$ & $\begin{array}{c}0.222 \\
4,229 \\
153\end{array}$ & $\begin{array}{c}0.188 \\
4,229 \\
153\end{array}$ \\
\hline
\end{tabular}

The Table reports dynamic panel fixed-effect coefficients. All models include a vector of country-pair fixed-effects, a vector of year fixed-effects and country-specific linear time trends. Standard errors are adjusted for country-pair level heteroskedasticity and autocorrelation and corresponding t-statistics are reported below the estimates. In odd-numbered specifications the dependent variable is minus one times the absolute difference in real GDP growth between country i and country $\mathrm{j}$ in year $\mathrm{t}$ (SYNCH1). In even-numbered specifications the dependent variable is minus one times the absolute difference of residual real GDP growth between country $\mathrm{i}$ and country $\mathrm{j}$ in year $\mathrm{t}$ (SYNCH2). All specifications include one lag of the dependent variable. In specifications (5)-(8) we control for the prodcut of the log level of GDP in country $i$ and country $j$.

BANKINTI denotes the one period lagged value of the average of the logs of bilateral stocks of assets and liabilities normalized by the sum of the two countries' population in year t. BANKINT2 denotes the one year lagged value of the average of the logs of bilateral stocks of assets and liabilities normalized by the sum of the two countries' GDP in year $t$. The Data Appendix and Section 3.1. gives details on the construction and the sources of all variables. The Table also gives the long-run coefficient of banking integration and the

corresponding $F$-score and $p$-value. 


\section{Supplementary Appendix Table A: Legislative Measures (Directives) of the Financial Services Action Plan (FSAP)}

Directive No. Directive Title

Deadline

1998/26/EC Implementation of the Settlement Finality Directive

2000/46/EC Directive on the taking up, pursuit and prudential supervision of the businesses of electronic money institutions

$27 / 04 / 2002$

2000/64/EC Directive amending the insurance directives and the ISD to permit Information exchange with third countries

$17 / 11 / 2002$

2001/17/EC Directive on the reorganisation and winding-up of Insurance undertakings

$20 / 04 / 2003$

2001/24/EC Directive on the reorganisation and winding-up of banks

2001/65/EC Directive amending the 4th and 7th Company Law Directives to allow fair value accounting

$5 / 5 / 04$

2001/86/EC Directive supplementing the Statute for a European Company with regard to the envolvement of employees

$9 / 10 / 2004$

2001/97/EC Directive amending the money laundering directive

$10 / 10 / 04$

2001/107/EC 1st Directive on UCITS (Undertakings for Collective Investments in Transferable Securities)

$15 / 06 / 2003$

$13 / 08 / 2003$

2nd Directive on UCITS (Undertakings for Collective Investments in Transferable Securities)

$13 / 08 / 2003$

2002/13/EC Directive amending the solvency margin requirements in the insurance directives

$20 / 09 / 2003$

2002/47/EC Directive on financial collateral arrangements

$17 / 12 / 2003$

2002/65/EC Directive on the Distance marketing of Financial Services

2002/87/EC Directive on the supervision of credit institutions, insurance undertakings and investment firms in a financial conglomerate

$1 / 01 / 2004$

$2002 / 83 / \mathrm{EC}$

Solvency 1 Directive for life insurance

$11 / 8 / 04$

2002/92/EC Directive on insurance mediation

2003/6/EC Directive on insider dealing and market manipulation

$20 / 09 / 2003$

$15 / 01 / 2005$

$12 / 10 / 04$

2003/41/EC Directive on the prudential supervision of pension funds

$23 / 09 / 2005$

2003/48/EC Directive on the taxation of savings income in the form of interest payments

$1 / 1 / 04$

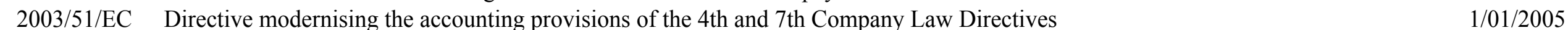

$2003 / 71 / \mathrm{EC}$

Directive on prospectuses

$1 / 07 / 2005$

2004/25/EC Directive on Take Over Bids

$5 / 20 / 06$

2004/109/EC Transparency Directive

$1 / 20 / 07$

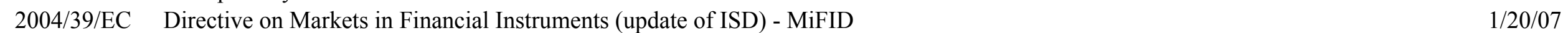

2005/56/EC 10th Company law Directive on cross-border mergers

$12 / 15 / 07$

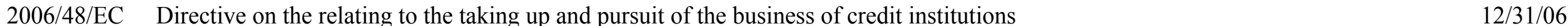

$2006 / 49 / \mathrm{EC}$

Directive on the capital adequacy of investment firms and credit institutions

$12 / 31 / 06$

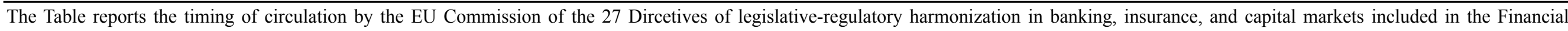
Services Action Plan (FSAP). Kalemli, Papaioannou, and Peydro (2010) give details on each of these Directives. 
Supplementary Appendix Table B: Transposition Date (Year Quarter) for the Directives of the Financial Services Action Plan (FSAP)

\begin{tabular}{|c|c|c|c|c|c|c|c|c|c|c|c|c|c|c|c|}
\hline Directive & AT & $\mathbf{B E}$ & DE & DK & ES & FR & FI & GR & IE & IT & $\mathbf{L U}$ & NL & PT & SE & $\mathbf{U K}$ \\
\hline 1998/26/EC & & 1999 Q2 & & & & & & & & & & & & & 1999 Q4 \\
\hline $2000 / 64 / \mathrm{EC}$ & 2003 Q3 & 2004 Q1 & 2002 Q1 & 2004 Q1 & $2002 \mathrm{Q} 4$ & 2006 Q1 & 2004 Q2 & 2004 Q4 & Not Yet & Not Yet & $2001 \mathrm{Q} 3$ & 2003 Q1 & 2000 Q4 & 2000 Q3 & 2003 Q2 \\
\hline 2001/17/EC & 2003 Q3 & 2004 Q4 & 2003 Q4 & 2006 Q3 & 2003 Q4 & 2005 Q1 & $2004 \mathrm{Q} 2$ & Not Yet & 2003 Q2 & 2003 Q2 & 2004 Q2 & $2004 \mathrm{Q} 2$ & $2003 \mathrm{Q} 2$ & $2006 \mathrm{Q} 2$ & $2003 \mathrm{Q} 2$ \\
\hline 2001/24/EC & 2003 Q3 & 2004 Q4 & 2004 Q1 & $2004 \mathrm{Q} 2$ & 2005 Q2 & 2004 Q4 & $2004 \mathrm{Q} 2$ & 2006 Q2 & $2004 \mathrm{Q} 2$ & 2004 Q3 & 2004 Q2 & 2005 Q2 & 2006 Q4 & 2006 Q1 & $2004 \mathrm{Q} 2$ \\
\hline 2001/65/EC & 2004 Q1 & 2005 Q1 & 2004 Q4 & 2002 Q1 & 2004 Q1 & 2004 Q4 & 2004 Q4 & 2006 Q2 & 2004 Q4 & 2005 Q1 & 2006 Q2 & 2005 Q3 & 2004 Q2 & 2004 Q1 & 2004 Q4 \\
\hline 2001/86/EC & 2004 Q4 & 2004 Q4 & 2004 Q4 & 2004 Q2 & 2006 Q3 & 2005 Q3 & 2004 Q4 & 2006 Q2 & 2006 Q4 & 2005 Q4 & 2006 Q3 & 2005 Q1 & 2005 Q4 & 2004 Q4 & 2004 Q4 \\
\hline 2001/97/EC & $2003 \mathrm{Q} 2$ & 2004 Q1 & 2002 Q3 & 2005 Q1 & 2003 Q3 & 2004 Q1 & $2003 \mathrm{Q} 2$ & 2005 Q4 & 2003 Q3 & 2004 Q1 & 2004 Q4 & $2001 \mathrm{Q} 4$ & $2004 \mathrm{Q} 2$ & 2005 Q1 & $2004 \mathrm{Q} 2$ \\
\hline 2001/107/EC & 2003 Q3 & $2004 \mathrm{Q} 2$ & 2004 Q1 & 2004 Q1 & 2004 Q1 & 2003 Q4 & & 2004 Q4 & 2003 Q4 & 2003 Q4 & 2003 Q1 & 2005 Q3 & 2004 Q1 & 2004 & 2004 Q1 \\
\hline 2001/108/EC & 2003 Q3 & $2004 \mathrm{Q} 2$ & 2004 Q1 & $2005 \mathrm{Q}$ & 2004 Q1 & 2003 Q4 & & 2004 & & & & & & & \\
\hline 2002/13/EC & 2003 Q3 & 2004 Q1 & 2004 Q1 & 2004 Q1 & 2004 Q1 & $2004 \mathrm{Q} 2$ & $2004 \mathrm{Q}$ & 2005 Q1 & 2005 Q1 & 2004 Q1 & 2004 Q2 & 2003 Q4 & 2003 Q4 & 2004 & 2004 Q1 \\
\hline $2002 / 47 / \mathrm{EC}$ & 2003 Q4 & 2005 Q1 & 2004 Q2 & 2004 Q4 & $2002 \mathrm{Q} 4$ & 2005 Q1 & 2004 Q1 & $2004 \mathrm{Q} 4$ & 2004 Q1 & & 2005 Q3 & & $2004 \mathrm{Q} 2$ & & 2005Q4 \\
\hline 2002/65/EC & 2004 Q4 & 2006 Q1 & 2004 Q4 & $2005 \mathrm{Q} 3$ & Not Yet & 2005 Q2 & $2005 \mathrm{Q} 2$ & 2005 Q2 & 2004 Q4 & 2005 Q4 & Not Yet & 2006 Q1 & Not Yet & 200 & 2004Q4 \\
\hline 2002/87/EC & 2005 Q1 & 2005 Q1 & 2005 Q1 & 2004 Q3 & 2005 Q2 & 2004 Q4 & 2004 Q3 & 2006 Q2 & 2005 Q1 & 2005 Q3 & 2006 Q4 & 2007 Q1 & Not Yet & 2006 Q3 & 2004 Q3 \\
\hline 2003/6/EC & 2005 Q1 & 2005 Q3 & 2004 Q4 & $2005 \mathrm{Q} 2$ & 2005 Q4 & 2005 Q3 & 2005 Q3 & 2005 Q3 & 2005 Q3 & 2005 Q2 & 2006 Q2 & 2005 Q4 & 2006 Q2 & 2005 Q3 & 2005 Q3 \\
\hline 2003/41/EC & 2005 Q3 & 2006 Q4 & 2005 Q3 & 2005 Q4 & 2005 Q1 & 2006 Q2 & & & & Not Yet & & 2006 Q1 & 2006 Q1 & 2006 Q1 & 2005 Q4 \\
\hline 2003/48/EC & 2004 Q1 & 2005 Q3 & 2005 Q1 & $2004 \mathrm{Q} 2$ & 2004 Q1 & 2003 Q4 & 2004 Q1 & 2005 Q1 & 2003 Q4 & 2005 Q2 & $2005 \mathrm{Q} 2$ & 2004 Q1 & 2005 Q3 & 2005 Q3 & 2005 Q1 \\
\hline 2003/51/EC & 2005 Q1 & 2006 Q1 & $2004 \mathrm{Q} 4$ & 2002 Q1 & & & & & 2005 Q1 & Not Yet & 2006 Q2 & 2005 Q3 & 2005 Q1 & 2006 Q1 & 2005 Q1 \\
\hline 2003/71/EC & 2005 Q3 & 2006 Q3 & 2005 Q3 & $2005 \mathrm{Q} 2$ & 2005 Q1 & 2005 Q3 & 2005 Q3 & 2005 Q4 & 2005 Q3 & Not Yet & 2005 Q3 & 2005 Q3 & 2005 Q2 & 2005 Q3 & 2005 Q3 \\
\hline & & & & & & & & & & & & & & & \\
\hline 2004/109/EC & 2007 Q4 & 2007 Q4 & 2007 Q4 & 2007 Q4 & 2007 Q4 & 2007 Q4 & 2007 Q4 & 2007 Q4 & 2007 Q4 & 2007 Q4 & 2007 Q4 & Not Yet & 2007 Q4 & 2007 Q4 & 2007 Q4 \\
\hline 2004/39/EC & $2007 \mathrm{Q} 2$ & 2008 Q3 & 2007 Q1 & 2007 Q2 & 2007 Q3 & 2007 Q4 & 2007 Q1 & 2007 Q2 & 2007 Q2 & 2007 Q4 & 2008 Q3 & 2007 Q4 & 2007 Q4 & 2007 Q1 & 2007 Q1 \\
\hline $2005 / 56 / \mathrm{EC}$ & 2007 Q4 & 2008 Q3 & 2007 Q2 & $2007 \mathrm{Q} 2$ & Not Yet & 2008 Q3 & 2007 Q4 & Not Yet & 2008 Q2 & 2008 Q3 & 2007 Q1 & 2008 Q3 & Not Yet & 2008 Q1 & 2007 Q4 \\
\hline 2006/48/EC & 2007 Q1 & $2007 \mathrm{Q} 4$ & 2006 Q4 & 2007 Q1 & 2008 Q1 & $2007 \mathrm{Q} 2$ & 2007 Q1 & 2007 Q3 & 2007 Q1 & 2007 Q1 & 2007 Q4 & 2007 Q1 & 2007 Q2 & 2007 Q1 & 2007 Q1 \\
\hline 2006/49/EC & 2007 Q4 & 2007 Q4 & 2006 Q4 & 2007 Q1 & 2008 Q1 & $2007 \mathrm{Q} 2$ & 2007 Q1 & 2007 Q3 & 2007 Q1 & 2007 Q1 & 2007 Q4 & 2007 Q1 & 2007 Q2 & 2007 Q1 & 2007 Q1 \\
\hline
\end{tabular}

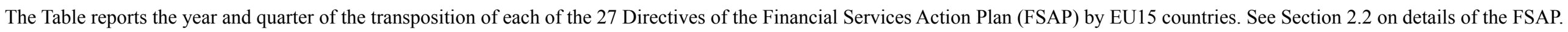

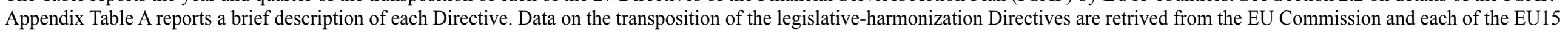
countries. 
Appendix Figure 1

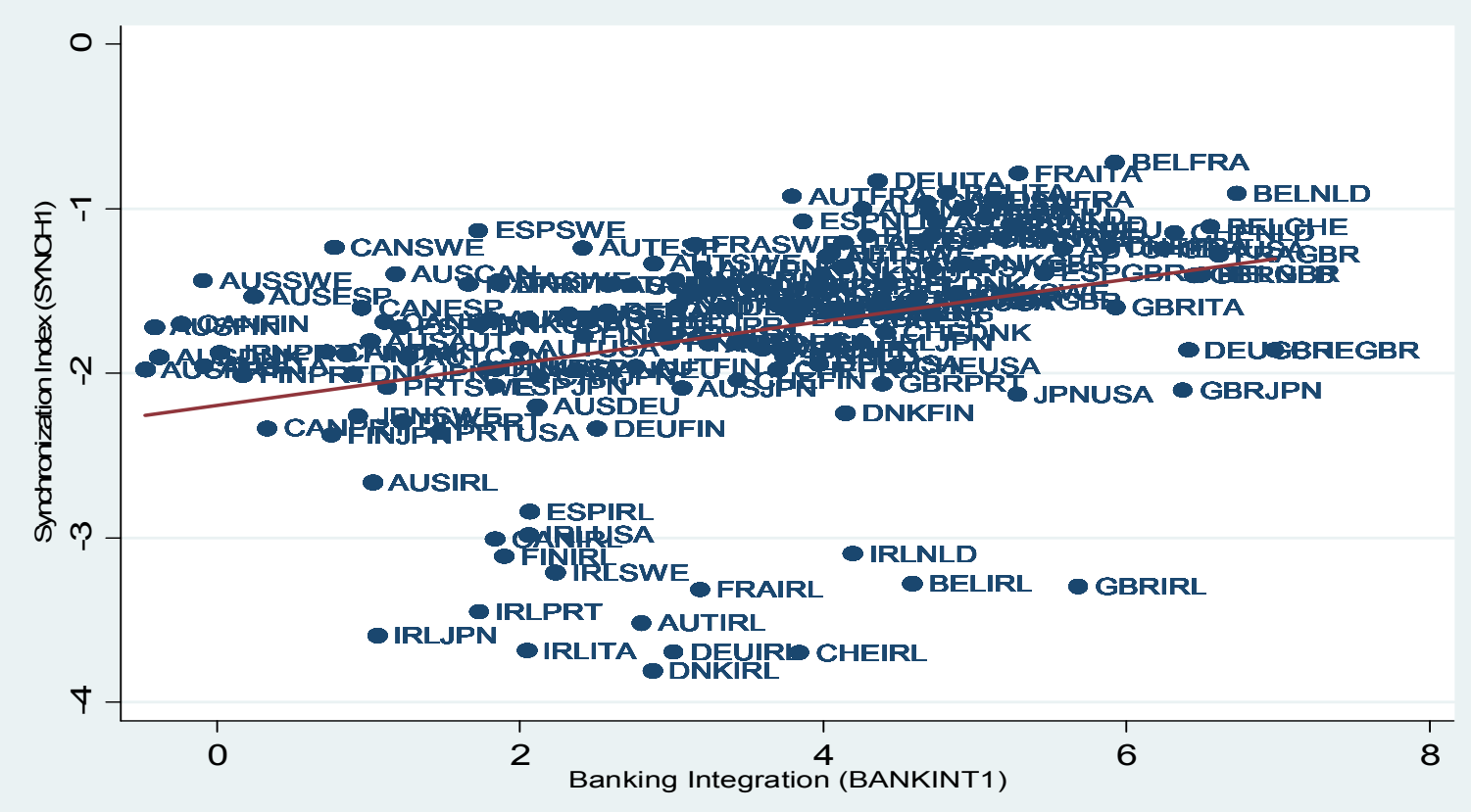

Appendix Figure 2

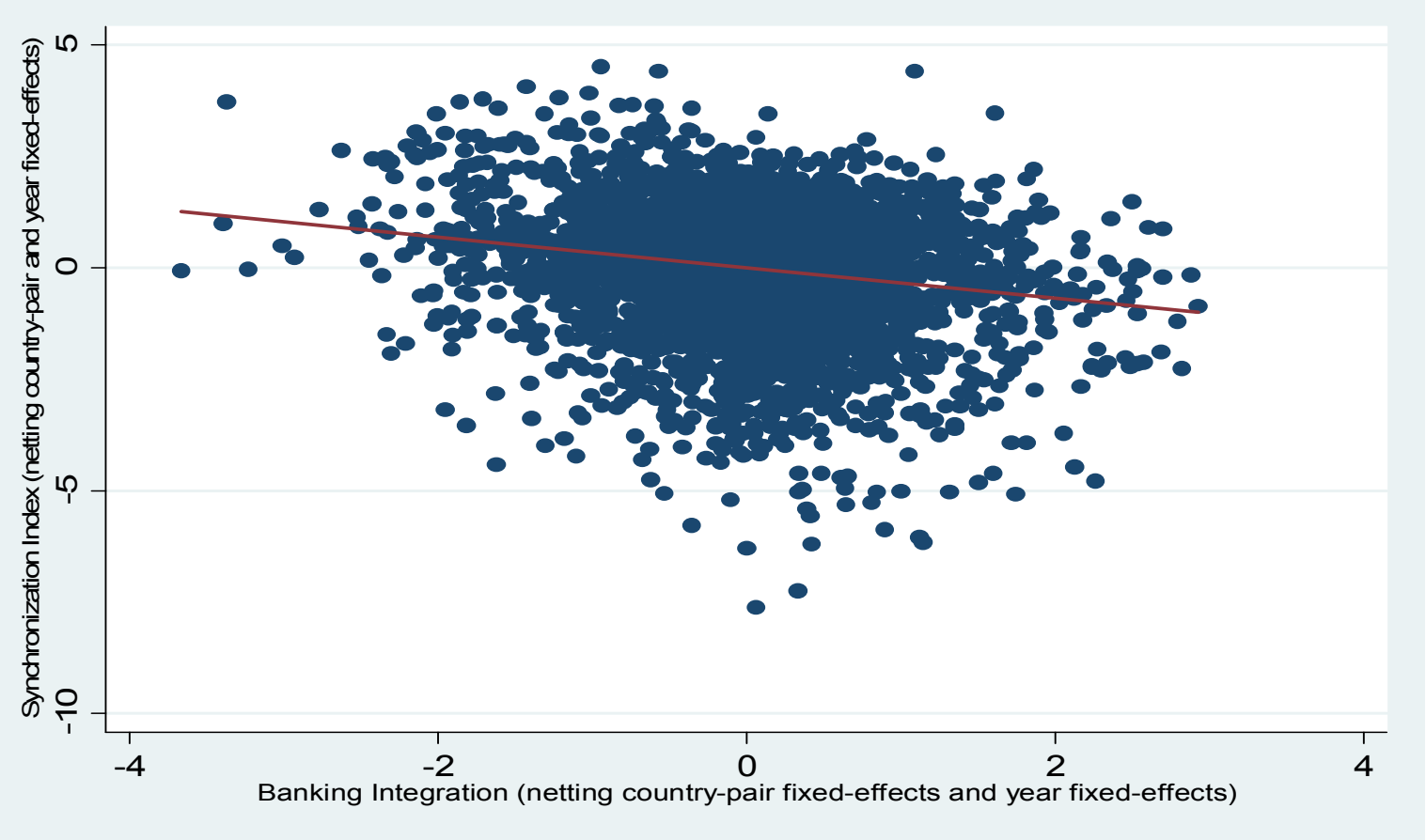

Appendix Figure 1 plots the cross-sectional correlation between output synchronization (SYNCH1) in the vertical axis and banking integration (BANKINT1) in the horizontal axis. Each observation corresponds to a country-pair and both output synchronization and banking integration are averages within each country-pair.

Appendix Figure 2 plots the within country-pair and within year correlation between output synchronization (SYNCH1) in the vertical axis and banking integration (BANKINT1) in the horizontal axis. Each observation corresponds to a particular country-pair in each year. To generate the figure we first regress output synchronization and banking integration on countrypair fixed-effects and year fixed-effects. Then we plot the residuals of the synchronization regression in the vertical axis against the residuals from the banking integration regression in the horizontal axis. 